\title{
Solute Fluxes Through Restored Prairie and Intensively Managed Critical Zones in Nebraska and lowa
}

\section{OPEN ACCESS}

Edited by:

Alexandra V. Turchyn, University of Cambridge,

United Kingdom

Reviewed by: Justin Byron Richardson, University of Massachusetts Amherst,

United States

Joel Moore,

Towson University, United States

*Correspondence:

Ashlee L. Dere

adere@unomaha.edu

Specialty section:

This article was submitted to

Biogeoscience,

a section of the journal

Frontiers in Earth Science

Received: 04 September 2018 Accepted: 04 February 2019

Published: 21 February 2019

Citation:

Dere AL, Miller AW, Hemje AM,

Parcher SK, Capalli CA and Bettis EA III (2019) Solute Fluxes

Through Restored Prairie and Intensively Managed Critical

Zones in Nebraska and lowa.

Front. Earth Sci. 7:24

doi: 10.3389/feart.2019.00024

\section{Ashlee L. Dere' ${ }^{1 *}$, Andrew W. Miller2, Amy M. Hemje², Sara K. Parcher', Courtney A. Capalli3 and E. Arthur Bettis III ${ }^{3}$}

${ }^{1}$ Department of Geography/Geology, University of Nebraska Omaha, Omaha, NE, United States, ${ }^{2}$ Department of Chemistry, University of Nebraska Omaha, Omaha, NE, United States, ${ }^{3}$ Department of Earth and Environmental Sciences, University of lowa, lowa City, IA, United States

Agricultural activities in the Midwestern United States have potentially altered geochemical fluxes within the critical zone (CZ) compared to native prairie systems that previously dominated the region. To quantify the impact of agricultural land use on soil and stream solute behavior, we are studying two watersheds in the region: Glacier Creek Preserve (GCP) in eastern Nebraska and the Intensively Managed Landscapes Critical Zone Observatory (IML-CZO) in eastern lowa. Both watersheds were initially under agricultural land use for over 100 years, but part of each watershed was restored to prairie 20 - 50 years ago. Soils at both sites formed in thick Peoria loess $(\geq 6 \mathrm{~m})$ overlying glacial till with similar mean annual temperatures $\left(\sim 10^{\circ} \mathrm{C}\right)$ but slightly higher mean annual precipitation in lowa $(89 \mathrm{~cm})$ compared to Nebraska $(78 \mathrm{~cm})$. At both sites, soil pore water and precipitation were collected every 2-4 weeks to measure anions, cations, and alkalinity; stream waters draining either restored prairie or agriculture were sampled similarly in Nebraska. Both soil moisture content and electrical conductivity were consistently higher in the upper one meter of agricultural soils compared to prairie soils in Nebraska, implying slower drainage and higher solute concentrations in the agricultural soils. At both sites, soil pore water $\mathrm{Ca}^{2+}$ and $\mathrm{Mg}^{2+}$ concentrations and annual fluxes were significantly higher in agricultural soils compared to restored prairie. Conversely, streams draining restored prairie have significantly higher $\mathrm{Ca}^{2+}$ and $\mathrm{Mg}^{2+}$ concentrations than the agricultural streams. Fluxes from agricultural streams, however, were higher than the prairie, pointing to a potential dilution effect of runoff from the agricultural land use. These observations lead to a conceptual model where deeply infiltrating water in restored prairie soils interacts with minerals present deeper in the soil before reaching the stream whereas in agricultural soils water does not infiltrate as deeply and thus experiences more shallow flowpaths to the stream. Furthermore, changes in geochemical and hydrologic fluxes have been realized in just a few decades since switching land use from agriculture to prairie. Thus, intensive agricultural land use may alter soil function and solute transport to streams compared to critical zones hosting tallgrass prairie vegetation.

Keywords: agriculture, soil pore water, loess, water quality, discharge, stream 


\section{INTRODUCTION}

The Midwestern United States hosts an impressively thick critical zone (CZ), the layer of the Earth that encompasses groundwater to vegetation (Brantley et al., 2007), with loess deposits exceeding $40 \mathrm{~m}$ deep in some areas (Bettis et al., 2003). Historically, the region hosted extensive prairie vegetation, but the landscape has been largely converted to agricultural land use since the $1800 \mathrm{~s}$ (Sampson and Knopf, 1994; Wright and Wimberly, 2013). Soils in this region sustain intensive agriculture, store large quantities of carbon, and filter water as it recharges groundwater and streams (Banwart, 2011), but how intensive agriculture influences CZ processes, including water and nutrient fluxes, and how long intensive land use can be maintained while sustaining high productivity, is unclear (Foley et al., 2005). Land disturbance from agriculture is widespread throughout the Midwestern United States and can have far reaching impacts on stream chemistry. Streams serve as integrators of $\mathrm{CZ}$ processes and, in the Midwest, ultimately deliver dissolved and particulate material to the Gulf of Mexico, impacting both the nutrient status and biology of waterways (Rabalais et al., 2010). Furthermore, there is evidence that intensive agriculture has altered the flow (Zhang and Schilling, 2006) and alkalinity (Raymond et al., 2008) of the Mississippi River, the largest river in North America. Despite the agronomic and environmental importance of the Midwestern CZ (Richardson and Kumar, 2017), we still know little about how activities at the surface influence $\mathrm{CZ}$ processes such as soil water fluxes and chemistry that are linked to streams.

Previous studies measuring soil and stream solute chemistry have largely focused on managed systems, such as row crop agriculture and pasture, and few studies have aimed to connect soil solute chemistry to stream chemistry in intensively managed systems. For example, previous studies investigating soil solutions under agricultural and grassland cover have primarily focused only on nitrate leaching (e.g., Masarik et al., 2014) and have been predominantly studied in sandy soils rather than finer textured soils (Singh et al., 2018). Furthermore, few studies involving in situ soil solution extractions concurrently use sensors to quantify soil moisture to investigate both soil solution chemistry and hydrology (Singh et al., 2018). Studies focused on stream fluxes from agricultural or restored prairie watersheds have also focused predominantly on nitrate and anion fluxes (e.g., Schilling, 2002; Aubert et al., 2013). Tallgrass prairie soils in the Midwest region have been most notably studied at the Konza Prairie Long Term Ecological Research (LTER) site in northeast Kansas, where soil water and gas fluxes through limestone and shale parent material have been linked to shallow groundwater chemistry (e.g., Tsypin and Macpherson, 2012; Vero et al., 2018). Previous work explicitly linking soil solute and stream water chemistry has largely focused on undisturbed forested systems (e.g., Jin et al., 2011; Hinckley et al., 2014) rather than row crop agriculture and prairie CZs.

To examine human influence on landscape connectivity and fluxes of water, sediment and nutrients in agroecosystems, the Intensively Managed Landscapes Critical Zone Observatory (IML CZO) was established (Kumar et al., 2018; Wilson et al., 2018). The CZO includes sites in Iowa, Illinois, and
Minnesota, representing a region characterized by thick surficial deposits from multiple glaciations (Anders et al., 2018) that has transitioned from transforming to transporting energy and matter under current human management practices (Kumar et al., 2018). Previous research at the IML CZO in the Clear Creek Watershed in Iowa has focused on hillslope (Papanicolaou et al., 2015a,b, 2018) and stream bank (Neal and Anders, 2015; Papanicolaou et al., 2017) erosion that delivers sediments and associated nutrients directly to streams. Meanwhile, groundwater monitoring has highlighted that baseflow discharge to the connected stream accounts for the majority of nitrate loads exported by the stream, $95 \%$ of which is derived from row crop areas (Schilling et al., 2018). However, soils represent an intermediate step in transmitting such nutrients to groundwater or streams, yet direct measurements of soil and stream solute chemistry are still needed (Singh et al., 2018; Wilson et al., 2018).

Here we present data on precipitation, soil pore water, and stream water chemistry, along with soil moisture and electrical conductivity (EC), under both corn-soybean row crop agriculture and restored prairie vegetation in loess parent material at sites in eastern Nebraska and eastern Iowa. The two study sites have similar topography, duration of soil formation, mean annual temperatures $\left(\sim 10^{\circ} \mathrm{C}\right)$, and a slight precipitation gradient $(78$ and $89 \mathrm{~cm}$ mean annual precipitation in Nebraska and Iowa, respectively). Both sites were used for agriculture for at least 100 years before portions of the sites were restored to prairie 20-50 years ago, thereby marking a substantial change in the aboveground vegetation and management. Given the similar environmental conditions between the two sites, we hypothesized that land use would be the main factor influencing soil hydrology and geochemistry, which in turn would impact stream chemistry. Solute measurements in this study focused on cations $\left(\mathrm{Na}^{+}, \mathrm{K}^{+}\right.$, $\mathrm{Mg}^{2+}$, and $\left.\mathrm{Ca}^{2+}\right)$ and anions $\left(\mathrm{Cl}^{-}, \mathrm{NO}_{2}{ }^{-}, \mathrm{NO}_{3}{ }^{-}, \mathrm{SO}_{4}{ }^{2-}\right.$, and $\left.\mathrm{PO}_{4}{ }^{3-}\right)$ in precipitation, soil pore water, and stream water as well as some metals $\left(\mathrm{Al}^{3+}, \mathrm{Fe}^{2+}, \mathrm{Fe}^{3+}\right.$, and $\left.\mathrm{Mn}^{2+}\right)$ in stream water. Using these geochemically relevant ion concentrations from the different water sample types, combined with soil and stream hydrologic characterization (soil moisture, soil EC, and stream discharge), we present an initial conceptual model demonstrating impacts of intensive agriculture and prairie land use on soil hydrology, geochemistry, and ultimately stream chemistry. Although the mechanisms driving these changes are yet unclear, the land use impacts on soil processes appear to alter the elemental fluxes from each land use despite less than 50 years since land use changed.

\section{MATERIALS AND METHODS}

\section{Study Sites \\ Glacier Creek Preserve}

Glacier Creek Preserve (GCP) is located in eastern Nebraska $20 \mathrm{~km}$ northwest of Omaha, NE, United States (Table 1 and Figures $1 \mathrm{~A}, \mathbf{B}$ ). The $4 \mathrm{~km}^{2}$ preserve encompasses the entire first order Glacier Creek watershed and includes both restored tallgrass prairie and agricultural land use on the gently rolling topography (slopes $<15 \%$ ). The site was used entirely for 
TABLE 1 | Sampling locations in Nebraska (NE) and lowa (IA) agriculture and restored prairie study sites.

\begin{tabular}{|c|c|c|c|c|}
\hline \multicolumn{2}{|l|}{ Site } & \multirow{2}{*}{\begin{tabular}{|l} 
Latitude \\
41.3455
\end{tabular}} & \multirow{2}{*}{$\begin{array}{l}\text { Longitude } \\
-96.1414\end{array}$} & \multirow{2}{*}{$\begin{array}{r}\text { Elev. } \\
\mathbf{m} \\
363\end{array}$} \\
\hline NE Agriculture & & & & \\
\hline NE Prairie & & 41.3373 & -96.1414 & 371 \\
\hline IA Agriculture & & 41.7390 & -91.9475 & 264 \\
\hline IA Prairie & & 41.7403 & -91.7322 & 248 \\
\hline \multirow[t]{5}{*}{ NE Stream } & GC2 & 41.3412 & -96.1405 & 322 \\
\hline & GC3 & 41.3414 & -96.1413 & 320 \\
\hline & GC4 & 41.3416 & -96.1421 & 323 \\
\hline & GC5 & 41.3408 & -96.1429 & 328 \\
\hline & GC6 & 41.3404 & -96.1448 & 348 \\
\hline
\end{tabular}

agriculture from approximately 1870 until 1970, when the southern $0.54 \mathrm{~km}^{2}$ of the preserve were reseeded to native tallgrass prairie (Figure 1C). The prairie vegetation is managed with a 3 year fire return interval with one third of the area burned each year. The northern portion of the site $\left(0.32 \mathrm{~km}^{2}\right)$ continues to be used for minimal till corn (Zea mays L.) and soybean [Glycine max (L.)] agriculture; tilling practices switched from intensive to minimal tillage around 1970. In 2017 soybeans were grown in the study area and broadcast phosphorous and potassium fertilizer was applied the previous fall following a corn harvest.

Parent material at the site is dominated by Peoria loess in the upland areas ( $>10 \mathrm{~m}$ thick) and pre-Illinoian glacial till underlies the creek that runs through the center of the watershed. Soils on the ridgetop topographic position, where soil sensors and soil pore water were collected, are mapped as Contrary-Monona-Ida Complex (Soil Survey Staff, 2018). On the agricultural side of the watershed, soils are Contrary silt loam (Fine-silty, mixed, superactive, mesic Dystric Eutrudepts) while prairie soils are Monona silt loam (Fine-silty, mixed, superactive, mesic Typic Hapludolls). Mean annual temperature is $10^{\circ} \mathrm{C}$ and mean annual precipitation is $78 \mathrm{~cm}$. In 2017, average air temperature was $11.8^{\circ} \mathrm{C}$ and precipitation in the watershed totaled $78 \mathrm{~cm}$.

\section{Intensively Managed Landscapes Critical Zone Observatory}

The Intensively Managed Landscapes Critical Zone Observatory (IML CZO) is located approximately $30 \mathrm{~km}$ northwest of Iowa

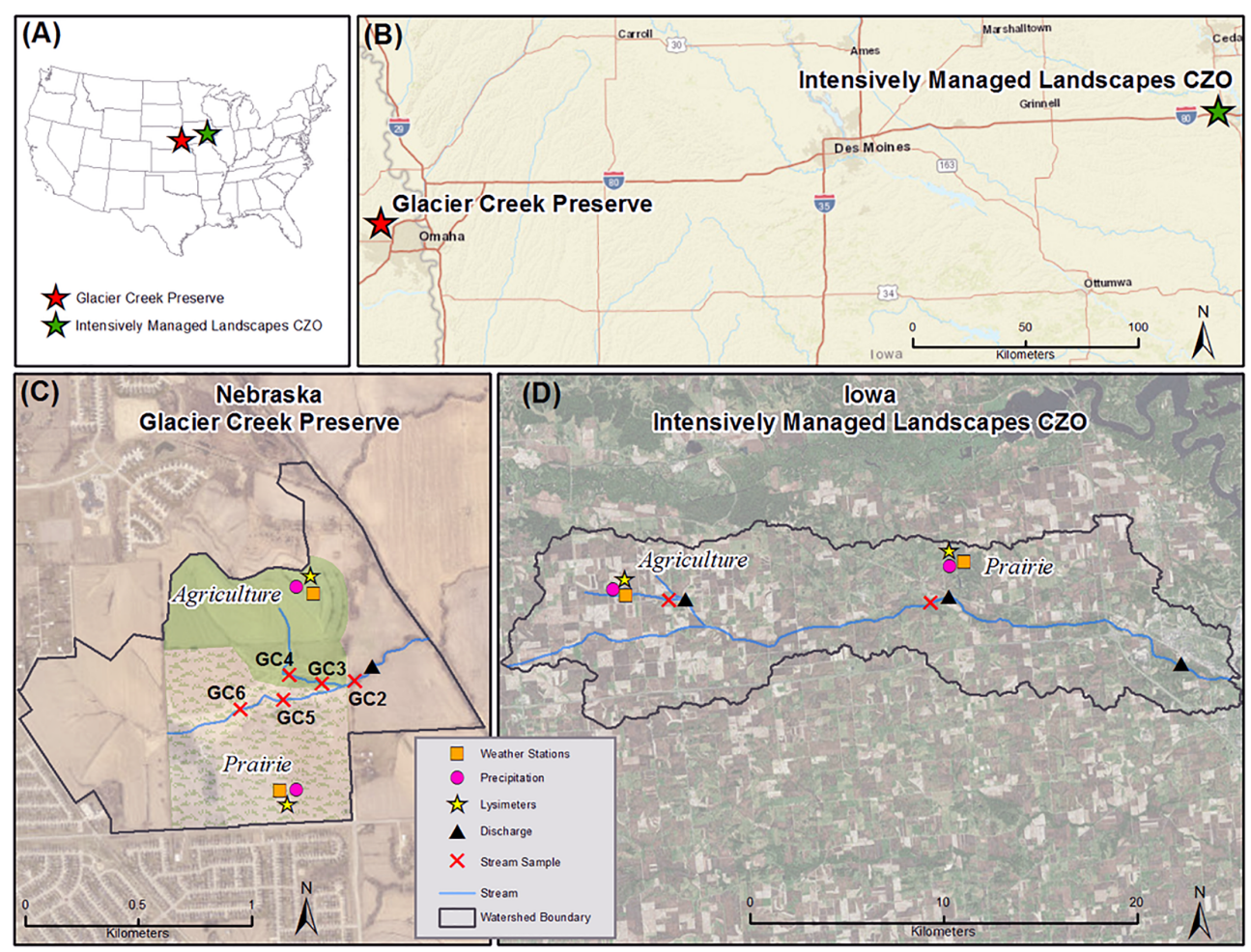

FIGURE 1 | Glacier Creek Preserve (GCP) and the Intensively Managed Landscapes Critical Zone Observatory (IML CZO) located in the Midwestern United States (A) approximately $400 \mathrm{~km}$ apart in eastern Nebraska (NE) and eastern lowa (IA) (B). The $4 \mathrm{~km}^{2}$ watershed in Nebraska is drained by Glacier Creek which has forks draining restored prairie on the south side of the watershed (hatched green shading) and agriculture on the north side (solid green shading) (C). The lowa site lies in the $270 \mathrm{~km}^{2}$ Clear Creek watershed and is drained by Clear Creek (D). This site includes an agricultural study site toward the headwaters and a restored prairie study site on the northern edge of the watershed. In both Nebraska and lowa, restored prairie and agricultural soils are equipped with weather stations, soil sensors, soil pore water samplers at four depths, and precipitation collectors. Glacier Creek is equipped with a stream discharge sensor and five stream locations were regularly sampled. Clear Creek has three discharge sensors monitored by the lowa Flood Information System (IFIS) (from west to east: Homestead, Oxford, and Coralville), but the stream is not routinely sampled for solute chemistry. 
City, IA (Table 1 and Figures $\mathbf{1 A}, \mathbf{B}$ ). The $270 \mathrm{~km}^{2}$ HUC 10 watershed is drained by Clear Creek and land use is dominated by roughly 100 years of agricultural land use across the gently rolling topography (slopes $<18 \%$ ) (Figure 1D). The agricultural study site is located on a farm in the northwest corner of the watershed where minimal tillage practices replaced more intensive chisel plow tillage in the 1990s (Papanicolaou et al., 2015b). In 2017 corn was grown in the study area with an application of broadcast phosphorous and potassium fertilizer and anhydrous ammonium following harvest of the soybean crop in 2016. Parent material at the site is Peoria loess ( $\sim 6 \mathrm{~m}$ thick) overlying Sangamon age glacial till. Soils are mapped as Tama silty clay loam (Fine-silty, mixed, superactive, mesic Typic Argiudolls) (Soil Survey Staff, 2018).

A small restored tallgrass prairie $\left(0.06 \mathrm{~km}^{2}\right)$ is located approximately $16 \mathrm{~km}$ to the east of the agricultural site in F.W. Kent Park. The prairie was originally forested prior to clearing for agriculture in the late 1800s; conventional corn-soybean row crop agriculture ceased in 1997. The site was left fallow until 2009 then reseeded with prairie grass mix; prairie vegetation is currently maintained through controlled burns every $\sim 5$ years. Parent material at the site is thin Peoria loess ( $\sim 1.6 \mathrm{~m}$ thick) overlying Sangamon age glacial till; soils at the site are Fayette silt loam (Fine-silty, mixed, superactive, mesic Typic Hapludalfs) (Soil Survey Staff, 2018). Mean annual temperature in the Clear Creek watershed is $9^{\circ} \mathrm{C}$ and mean annual precipitation is $89 \mathrm{~cm}$. In 2017, average air temperature was $12.1^{\circ} \mathrm{C}$ and $123 \mathrm{~cm}$ of precipitation was recorded near the agricultural study area.

\section{Sensor Data}

\section{Meteorological Stations and Soil Sensors}

At the Nebraska study site, two meteorological stations were installed on ridgetop topographic positions, one in the restored prairie and one in the agricultural field. Both stations provided hourly measurements of atmospheric and soil parameters at 10, 25, 50, and $100 \mathrm{~cm}$ depth (Figure 1C). The Campbell Scientific (Logan, UT, United States) meteorological stations recorded data on a CR1000 datalogger with the following sensors: anemometer (R.M. Young's 03002 Wind Sentry Set), all season pyranometer (SP230), precipitation sensor (Texas Electronics Tipping Bucket Rain Gages), temperature and relative humidity sensor (HC2S3), barometer (CS106), and soil moisture, temperature and electrical conductivity (EC) sensors (CS655).

At the IML CZO in Iowa, a meteorological station recorded atmospheric parameters on a ridgetop topographic position at the agricultural study site (Figure 1D). The Meter (Pullman, WA, United States) meteorological station collected data with EM50 dataloggers including precipitation (ECRN-100 tipping bucket), wind speed and direction (Davis Cup anemometer), and relative humidity and temperature (VP-3) at $1 \mathrm{~min}$. intervals. Soil parameters at 10,20 , and $60 \mathrm{~cm}$ depth were measured at both the agricultural and restored prairie sites every $15 \mathrm{~min}$. Soil moisture and temperature were measured with a 5TM Moisture/Temperature sensor at the agricultural site and a GS3 Soil Moisture/Temperature/EC sensor at the restored prairie site.

\section{Stream Water Quality}

General stream water quality parameters were collected in the field at the Nebraska site using Xylem (Rye Brook, NY, United States) ProDSS handheld sensors. The parameters included pH/oxidation reduction potential (ORP, 626904), temperature/conductivity (626902), turbidity (626901), and optical dissolved oxygen (626900). Measurements were taken approximately every 2 weeks at each of five sampling sites (Figure 1C). Each probe was calibrated with relevant calibration solutions on the day of sampling. Before taking a measurement, the probes were placed in the stream for several minutes to allow the probes to equilibrate and allow fresh water to displace any sediment disturbed by the placement of the probes.

\section{Stream Discharge}

A SonTek Xylem IQ in situ stream discharge sensor was placed in Glacier Creek at the Nebraska study site downstream of the GC2 sampling site in May 2017 (Figure 1C). The IQ system simultaneously measured the flow velocity and the stream channel dimensions using sound waves, which was then converted to volumetric flow. The IQ was programmed to log flow data every $15 \mathrm{~min}$. In Iowa, several discharge sensors along Clear Creek recorded hourly discharge at the Homestead, Oxford and Coralville gaging stations ${ }^{1}$ (Figure 1D).

\section{Solute Sampling Stream Water}

Stream water samples were collected approximately monthly from all five sites in Glacier Creek in Nebraska beginning in April through December 2017. For data analysis purposes, four of the sampling locations were sorted based on physical proximity to either prairie or agricultural land uses. Locations GC3 and GC4 are physically closest to active agriculture and are located on the north fork of Glacier Creek, which drains predominantly agricultural land. Locations GC5 and GC6 are physically closest to the restored prairie and are located in the south fork of Glacier Creek, which drains the majority of the restored prairie. Site GC2 is located just below the convergence of the two forks, and was used for mass balance calculations described below. At each site, a grab sample was removed from the stream with a conditioned sampling beaker. The sample was filtered through a $0.45 \mu \mathrm{m}$ PVDF syringe filter and then split. One split was left unacidified for anion and alkalinity analysis, the other split was acidified to $\mathrm{pH}<2$ with concentrated $\mathrm{HCl}$. All samples were refrigerated at $4^{\circ} \mathrm{C}$ prior to analysis.

Clear Creek in the Iowa IML watershed predominantly drains agricultural land use in the headwaters and mixed urban and agricultural land use toward the mouth of the watershed, but does not have a stream draining predominantly restored prairie like in Nebraska. Grab samples from the Homestead gaging station (westernmost triangle in Figure 1D), which is located near the agriculture study site, were collected on two dates (201506-25 and 2016-12-01) and analyzed for cations and anions as described below.

\footnotetext{
${ }^{1}$ http://ifis.iowafloodcenter.org/ifis/app/
} 


\section{Soil Pore Water}

Suction cup pore water samplers with a silicon carbide cup (SIC20) (UMS brand; Munich, Germany) were installed at four different depths in both restored prairie and agricultural land use at the Nebraska and Iowa study sites. Samplers were installed in spring - summer of 2016 to allow time for porous cups to equilibrate with soil conditions (Singh et al., 2018). Pore water samplers were inserted at an approximately $20^{\circ}$ angle away from vertical into a hand-drilled hole using a custom gouge auger (TB-20 and TBE-100). In Nebraska, pore water samplers were installed at 10, 25, 50, and $100 \mathrm{~cm}$ depth; in Iowa, samplers were installed at 20,60, 80, and $150 \mathrm{~cm}$ depth. Pore water samplers were connected to $500 \mathrm{ml}$ glass sampling bottles (SF-500) and stored in an insulated plastic box (SF-box) buried in the ground. Sample bottles were evacuated down to $\sim 0.5$ bar using a hand-operated vacuum floor pump (VPS-2) in Nebraska and an automated portable vacuum (VacuPorter) in Iowa. The vacuum was removed from all samplers and the site covered in straw from December to March to avoid frost damage to the pore water samplers.

Soil pore water was collected approximately every 2 weeks from May through November and the sample volume, $\mathrm{pH}$, and electric conductivity were recorded in the field. Samples were filtered through a $0.45 \mu \mathrm{m}$ PVDF syringe filter and then split. One split was left unpreserved for anion and alkalinity analysis, the other split was acidified to $\mathrm{pH}<2$ with concentrated nitric acid for cation analysis. All samples were refrigerated at $4^{\circ} \mathrm{C}$ prior to analysis. At both sites, insufficient sample volume limited some or all chemical analyses, especially during the driest parts of the year in late summer (Supplementary Tables 1-4).

\section{Precipitation}

Precipitation was collected every 2 weeks at the Iowa agriculture and prairie sites and at the Nebraska prairie site. The collection vessel included a plastic funnel covered by wire mesh connected by zip ties to a $250 \mathrm{ml}$ plastic separatory funnel. A thin layer of mineral oil was added to prevent evaporation. A subsample was collected and filtered through a $0.45 \mu \mathrm{m}$ PVDF syringe filter and then split and preserved in the same manner as the pore water samples. On some occasions, the volume of rainwater exceeded the capacity of the collection vessel or the addition of bird fecal matter contaminated precipitation samples and precluded their inclusion in the dataset (Supplementary Table 5).

\section{Chemical Analyses}

\section{Cations and Anions}

For all water samples, bulk ions $\left(\mathrm{Na}^{+}, \mathrm{K}^{+}, \mathrm{Mg}^{2+}, \mathrm{Ca}^{2+}, \mathrm{Cl}^{-}\right.$, $\mathrm{NO}_{2}{ }^{-}, \mathrm{NO}_{3}{ }^{-}, \mathrm{SO}_{4}{ }^{2-}$, and $\mathrm{PO}_{4}{ }^{3-}$ ) were determined using a Dionex Aquion ion chromatograph using CS12A analytical and guard columns for cation analysis, and AS23 analytical and guard columns for anion analysis (Supplementary Tables 1-10). Trace metal analysis $\left(\mathrm{Al}^{3+}\right.$ and $\mathrm{Mn}^{2+}$ ) was completed on a Varian inductively coupled plasma mass spectrometer (ICP-MS) (Walnut Creek, CA, United States). Total dissolved iron $\left(\mathrm{Fe}^{2+}\right.$ and $\left.\mathrm{Fe}^{3+}\right)$ was determined through complexation with phenanthroline on an Agilent Technologies Cary 8454 UV-Vis spectrophotometer (Santa Clara, CA, United States). For the instrumental methods, initial method validation was completed using sample spikes, dilutions, and replicate samples. For each analytical run, calibration standards and check standards were analyzed to ensure data quality.

\section{Alkalinity}

Stream sample alkalinity determinations were completed within $24 \mathrm{~h}$ of sampling. Potentiometric alkalinity titrations were completed on $50 \mathrm{~mL}$ aliquots of stream samples using a Hannah Instruments (Woodsocket, RI, United States) autotitrator with standardized $\mathrm{HCl}$. When possible, titrations were completed on pore water samples. Due to sample volume limitations, only $7 \mathrm{~mL}$ of sample were used.

\section{Data Analyses \\ Flux Calculations}

Since stream flow rate was only directly measured after the south fork (prairie) and north fork (agriculture) of Glacier Creek had converged (Figure 1C), mass balance calculations using conservative ions were used to split the total flow on the date of sampling into flow rates for each fork of the creek. Concentrations of several different ion pairs $(\mathrm{Na} / \mathrm{Cl}$, $\mathrm{K} / \mathrm{Cl}$, and $\mathrm{Ca} / \mathrm{Cl}$ ) from sampling positions just above and just below fork convergence were used to estimate the two fork flows (Davis and Cornwell, 1998). Once the flow for each fork was known, the flow was multiplied by the stream concentration and normalized to drainage area at the most downgradient sampling point on both the south fork and north fork to determine the elemental flux emanating from the prairie and agricultural land uses, respectively. During the driest parts of the year (fall/winter) total stream flow was frequently too low to be reliably measured. For months where the IQ sensor was not accurately capturing the total flow rate (September, October, and December), average monthly flow for each fork was estimated by averaging July, August, and November monthly discharges, which were considered to represent baseflow conditions at the site (i.e., not influenced by spring flush) (Supplementary Table 11).

Similarly, soil pore water fluxes were determined for each sample by multiplying elemental concentration by the collected volume and dividing by the area over which each pore water sampler suction cup captures water $\left(25 \mathrm{~cm}^{2}\right)$ and the sampling period ( $\sim 14$ days) (Supplementary Tables 12-14) (Weihermuller et al., 2007). Soil pore water fluxes were averaged over all depths for the year at each site to determine an average flux by site and land use.

\section{Speciation}

All speciation calculations were completed using PHREEQC (Parkhurst and Appelo, 2013). For stream samples, where all major ions had been directly measured for every sample, the ion concentrations and basic water quality parameters ( $\mathrm{pH}$, dissolved oxygen, temperature) were used as input to calculate the error in the charge balance, saturation indices for relevant mineral species, and the partial pressure of $\mathrm{CO}_{2}$ $\left(\mathrm{P}_{\mathrm{CO} 2}\right)$. Each stream water sample was speciated individually, and the annualized results from the prairie or agricultural stream 
locations were averaged for analysis. For the pore water samples, volume limitations precluded direct determination of all ion concentrations in every sample. Some samples had either anion or cation analysis but not both, many were missing alkalinity values, and no samples had trace metal analysis ( $\mathrm{Fe}, \mathrm{Mn}$, or $\mathrm{Al}$ ). Since each sample could not be speciated individually, the annual average concentration for each measured ion was used instead. Pore water samples were averaged by land use type in Nebraska and Iowa; individual ion concentrations from all prairie related samples were averaged and individual ion concentrations from all agricultural samples were also averaged. To remove any outliers from consideration, concentrations larger than two standard deviations above the mean were not included. Non-detectable ion concentrations were also omitted from averaging. Non-detectable concentrations were common for $\mathrm{NO}_{2}{ }^{-}$and $\mathrm{PO}_{4}{ }^{3-}$, while the other major ions were more consistently detected.

\section{Statistics}

Differences between agriculture and restored prairie solute concentrations, soil moisture and soil EC were analyzed for significant differences using a two-sample student $t$-test $(\alpha=0.05)$ using OriginLab software (Wellesley Hills, MA, United States). The statistical test compared the agriculture and restored prairie data at each site individually (e.g., Nebraska prairie vs. Nebraska agriculture, Iowa prairie vs. Iowa agriculture).

\section{RESULTS}

\section{Soil Moisture and Electrical Conductivity}

Soil moisture (volumetric water content) throughout the year was higher overall in agricultural soils in Nebraska compared to prairie soils, especially March through May (Figure 2A). Prairie soil moisture responded rapidly to precipitation events in the upper $25 \mathrm{~cm}$ but an increase in soil moisture was often observed down to $100 \mathrm{~cm}$ following a precipitation event. In contrast, the agricultural soil responded rapidly to precipitation events predominantly in the upper $25 \mathrm{~cm}$, but soil moisture at deeper depths tended to show no immediate response to incoming precipitation. Iowa soil moisture was higher overall throughout the year in the prairie soil compared to the agricultural soil, but at all depths soil moisture tended to increase immediately following a precipitation event (Figure 2B). In Nebraska, the average soil moisture was significantly lower $(p<0.05)$ in the upper $25 \mathrm{~cm}$ of restored prairie soils compared to agricultural soils (Supplementary Table 15 and Figure 3A). The opposite was observed in Iowa, where average soil moisture at all depths was greater in prairie soils than agricultural soils (Figure 3B).

Soil electrical conductivity (EC), an indication of the dissolved solutes present in the soil water, was higher at all depths in Nebraska agricultural soils compared to prairie soils, especially during the summer months (Figure 2A). The agricultural soil EC showed an annual trend whereby EC increased steadily March through June and then slowly decreased through the rest of the year. In Iowa, where only prairie soil EC data were available, EC was relatively constant throughout the year, increasing in response to fall precipitation following the driest part of summer (Figure 2B). Soil EC was significantly higher $(p<0.05)$ at all depths in the agricultural soil than the prairie soils in Nebraska, with average EC increasing with depth under both land uses (Figure 3C). In Iowa, average EC at 10 and $60 \mathrm{~cm}$ depth was similar within uncertainty to EC measured in Nebraska prairie
A

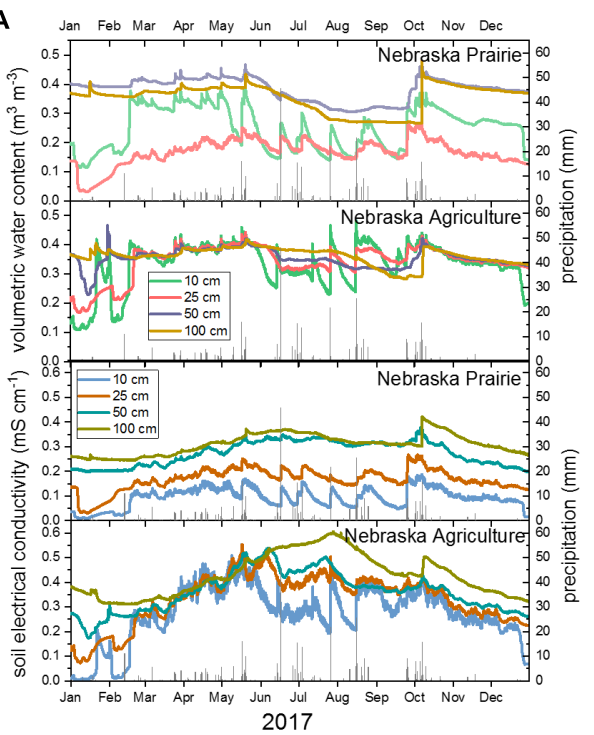

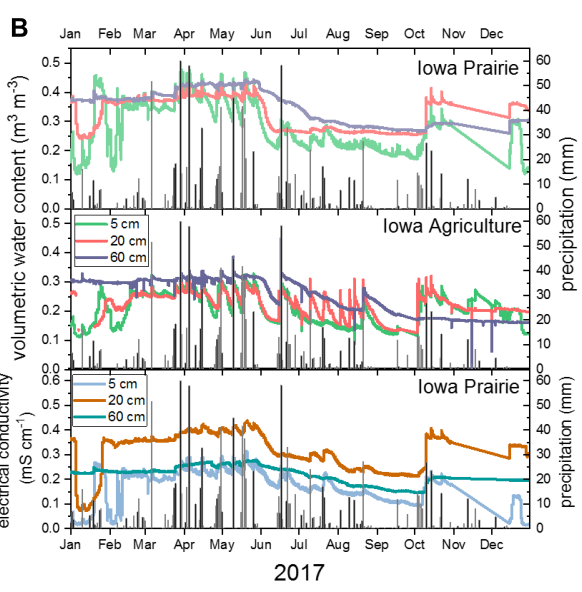

2017

FIGURE 2 | Annual time series data for soil moisture (volumetric water content), soil electrical conductivity, and precipitation in Nebraska (A) and lowa (B) restored prairie and agricultural sites. Colored lines indicate different measurement depths at each site and gray bars represent precipitation events. No soil electrical conductivity data is available at the lowa agricultural site. 


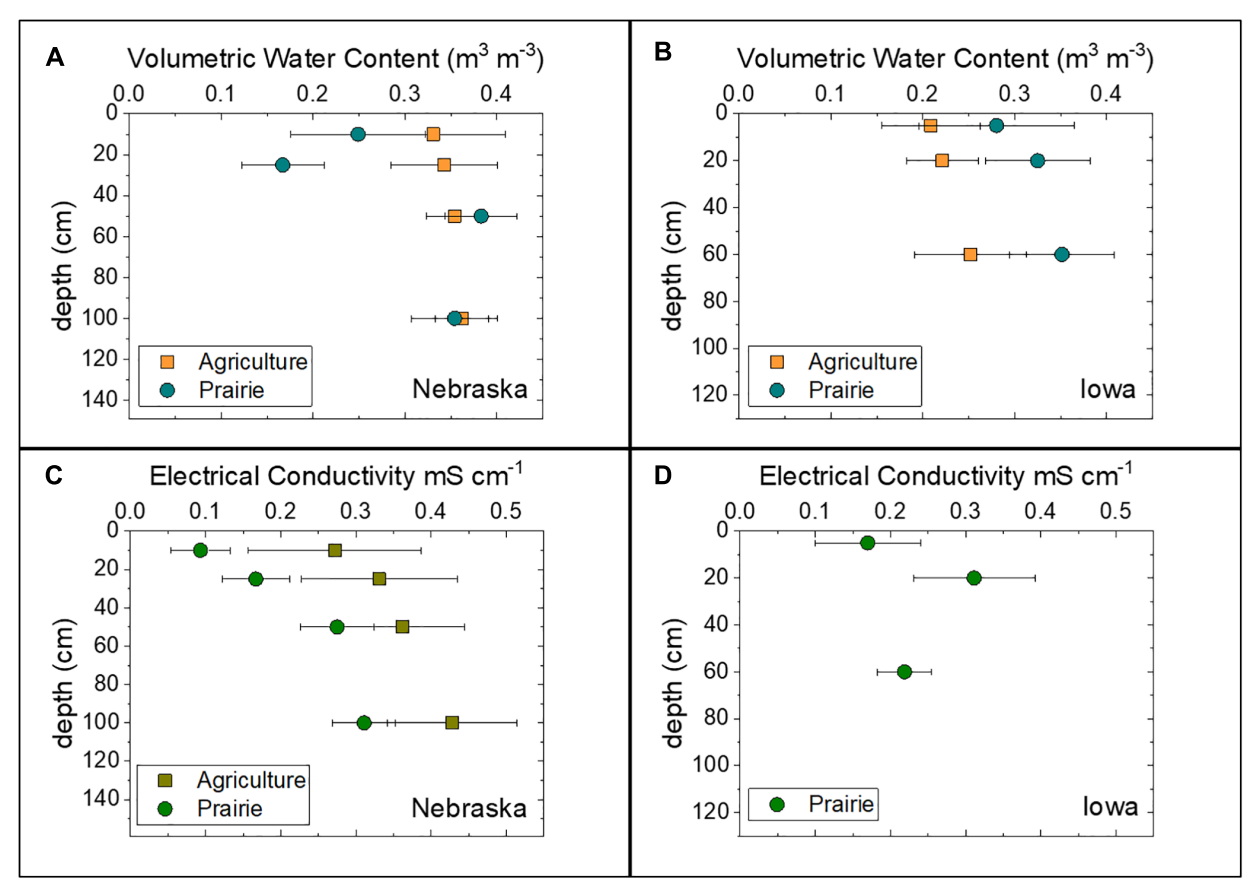

FIGURE $\mathbf{3}$ | Annual average soil volumetric water content and electrical conductivity with depth at the Nebraska $\mathbf{( A , C )}$ and lowa (B,D) study sites for both agriculture and restored prairie land use. Black bars indicate one standard deviation around the mean.

soils, with a measurable increase then decrease in EC with depth (Figure 3D).

\section{Discharge}

The average total stream flow for the studied period was $0.0113 \mathrm{~m}^{3} \mathrm{sec}^{-1}$ with a median flow rate of $0.0060 \mathrm{~m}^{3} \mathrm{sec}^{-1}$. The flow was $<0.003 \mathrm{~m}^{3} \mathrm{sec}^{-1} 10 \%$ of the time, and $<0.023 \mathrm{~m}^{3}$ $\sec ^{-1} 90 \%$ of the time. Based on the mass balance calculations, the south fork of Glacier Creek accounted for an average of $22 \%$ of the total flow (range: 12-31\%) while the north fork accounted for an average of $78 \%$ of the total flow (range: $59-88 \%$ ). There did not appear to be a relationship between total flow and the flow distribution between the two forks. The highest flows occurred in May and June; lowest flows occurred in September to December.

\section{Solute Chemistry}

\section{Cations}

In the agricultural soils, pore water annual average cation concentrations were significantly higher $(p<0.05)$ for $\mathrm{Ca}^{2+}$ and $\mathrm{Mg}^{2+}$, but not $\mathrm{Na}^{+}$and $\mathrm{K}^{+}$, in both Nebraska and Iowa (Figures $4 \mathrm{~A}, \mathbf{B}$ ). As with the concentrations, annual average $\mathrm{Ca}^{2+}$ and $\mathrm{Mg}^{2+}$ elemental fluxes in agricultural soil pore waters were higher at both Nebraska and Iowa, but the difference is significant only in Iowa (Figures 4C,D). At all measured depths, soil pore water cation concentrations were lower in prairie than agricultural soils (Supplementary Figure 1).

For stream water concentrations in Nebraska, all of the major cations except for $\mathrm{Na}^{+}$were significantly higher $(p<0.05)$ in stream locations draining restored prairie compared to stream locations draining agricultural fields (Table 2 and Figure 5). Conversely, $\mathrm{Na}^{+}$was significantly lower in streams draining prairie land use. However, the cation fluxes in the stream were higher in water draining agricultural fields (Table 3 ). The concentrations of redox active species $(\mathrm{Fe} / \mathrm{Mn})$ were also significantly higher in the prairie locations. Aluminum concentrations were consistently just above the detection limit for the ICP-MS (0.7 ppb), and were not different between the prairie and agriculture associated sections of the stream. Stream fluxes for the major cations associated with agriculture were higher than the elemental fluxes from prairie (Figure 5).

\section{Anions}

Soil pore water $\mathrm{Cl}^{-}$and $\mathrm{NO}_{3}{ }^{-}$concentrations were higher overall in Nebraska compared to Iowa, but only $\mathrm{NO}_{3}{ }^{-}$concentrations were significantly higher $(p<0.05)$ in agricultural soils compared to prairie soils in Nebraska; anion concentrations were not significantly different amongst soil pore waters in Iowa (Figure 6). Very little $\mathrm{NO}_{3}{ }^{-}\left(<1 \mathrm{mg} \mathrm{L}^{-1}\right)$ was detected in either agriculture or prairie soil pore waters in Iowa. Masarik et al. (2014) measured mean annual $\mathrm{NO}_{3}{ }^{-}-\mathrm{N}$ leachate concentrations of $12.2 \mathrm{mg} \mathrm{L}^{-1}$ under no till corn crops and $<0.1 \mathrm{mg} \mathrm{L}^{-1}$ under restored prairie vegetation in silty loess soils with a similar climate to our study. The Iowa site has much lower $\mathrm{NO}_{3}{ }^{-}$concentrations under agriculture than the Masarik et al. (2014) data, while the average under Nebraska agriculture is much higher $\left(42 \pm 51 \mathrm{mg} \mathrm{L}^{-1}\right)$, although highly variable. The concentrations under the prairie land use at both locations are within an order of magnitude of Masarik et al. (2014). At this point it is not clear if the 

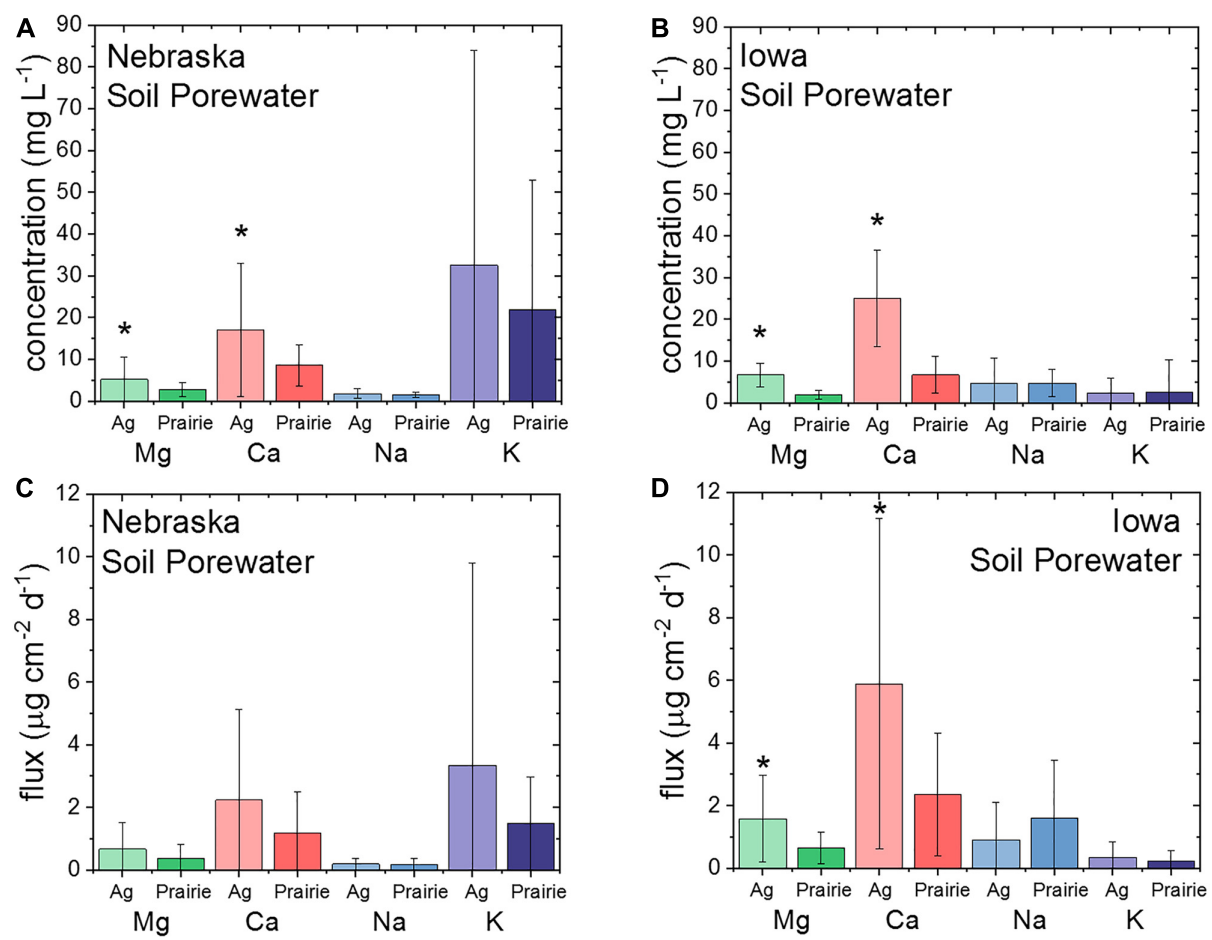

FIGURE 4 | Annual average soil pore water cation concentrations and fluxes at the Nebraska (A,C) and lowa (B,D) study sites for both agriculture and restored prairie land use. Stars indicate significant differences $(p<0.05)$ between land uses at that site and black bars indicate one standard deviation around the mean.

variability in concentrations are related to fertilizer application rates or varied biogeochemical cycling rate of nitrogen at the different sites.

Similar to the cations, major stream anion concentrations $\left(\mathrm{Cl}^{-}\right.$ and $\left.\mathrm{SO}_{4}{ }^{2-}\right)$ were significantly higher $(p<0.05)$ in the prairie locations than they were in the agricultural stream (Figure 6). The minor anions $\left(\mathrm{NO}_{2}^{-}, \mathrm{PO}_{4}{ }^{3-}\right)$ were frequently nondetectable. Nitrate concentrations were more reliably detected, but were not significantly different between streams draining prairie and agriculture in Nebraska. When detectable in Nebraska stream samples, $\mathrm{NO}_{3}{ }^{-}$concentrations were typically $<0.4 \mathrm{mg}$ $\mathrm{L}^{-1}$. In both the prairie and agricultural stream stretches, there was a pulse (>10 $\mathrm{mg} \mathrm{L}^{-1}$ ) of $\mathrm{NO}_{3}{ }^{-}$in early spring (March for agriculture, and April for prairie) (Supplementary Tables 6-10). The juxtaposition in time implies a spring flush of $\mathrm{NO}_{3}{ }^{-}$from both systems, but longer time scales are needed to confirm the large episodic $\mathrm{NO}_{3}{ }^{-}$exports. Nitrite concentrations were typically too low to be detected $(<11 \mathrm{ppb})$, but they generally followed the $\mathrm{NO}_{3}{ }^{-}$concentrations. Phosphate was also generally too low to be detected ( $<19 \mathrm{ppb})$. When it was detected, the SI for hydroxyapatite was generally undersaturated (SI range: -4.8 to -0.08 ) implying a non-mineral control on $\mathrm{PO}_{4}{ }^{3-}$ concentrations.

\section{Alkalinity}

The alkalinity was significantly higher in the stream waters associated with the prairie (Tables 4, 5). Unlike other major ions, the pore water data was not consistent between agriculture and prairie between the two study sites. In Nebraska, the pore waters had slightly higher alkalinity under the prairie, but in Iowa the alkalinity was noticeably lower under the prairie.

\section{Speciation}

The results from the speciation calculations are shown in Table 5. For stream samples, the average error in the charge balance for all speciated samples was 5.8\% (with excess anions), indicating the combination of analyses was likely complete and accurate. For pore waters, the average error in the charge balance was $6.9 \%$, also with excess anions.

\section{DISCUSSION}

Using the collected data, a conceptual model is constructed below that shows soil hydrology and geochemistry, and ultimately stream chemistry, differ based on land use. The data point to a model where precipitation drains more rapidly and deeper under prairie land use, and much slower and shallower under agricultural land use. It also appears that some of the precipitation falling on agricultural soils does not infiltrate at all, and instead runs off directly to the stream. The differences in soil hydrology influence soil pore water chemistry, especially $\mathrm{Ca}^{2+}$ and $\mathrm{Mg}^{2+}$ fluxes, which in turn impact stream chemistry. Such changes in geochemical and hydrologic fluxes have been realized in just a few decades since switching land use from agriculture to prairie. 
TABLE 2 | Average cation concentrations for stream waters, pore waters, and precipitation from Nebraska and lowa study sites under agriculture and restored prairie land use.

\begin{tabular}{|c|c|c|c|c|c|c|c|c|c|}
\hline \multirow[b]{3}{*}{ Ion } & \multicolumn{2}{|c|}{ Precipitation } & \multicolumn{2}{|c|}{ Pore Water } & \multicolumn{5}{|c|}{ Stream Water } \\
\hline & \multirow[t]{2}{*}{ Agriculture } & \multirow[t]{2}{*}{ Prairie } & \multirow[t]{2}{*}{ Agriculture } & \multirow[t]{2}{*}{ Prairie } & \multirow[b]{2}{*}{ GC2 } & \multicolumn{2}{|c|}{ Agriculture } & \multicolumn{2}{|c|}{ Prairie } \\
\hline & & & & & & GC3 & GC4 & GC5 & GC6 \\
\hline \multicolumn{10}{|l|}{ Nebraska } \\
\hline$n$ & --- & 6 & 30 & 31 & 10 & 10 & 11 & 11 & 10 \\
\hline $\mathrm{Na}^{+}(\mathrm{mg} / \mathrm{L})$ & --- & $\begin{array}{l}0.498 \\
(0.48)\end{array}$ & $\begin{array}{l}1.79 \\
(1.2)\end{array}$ & $\begin{array}{c}1.55 \\
(0.64)\end{array}$ & $\begin{array}{l}19.9 \\
(5.9)\end{array}$ & $\begin{array}{l}20.6 \\
(6.2)\end{array}$ & $\begin{array}{l}21.8 \\
(7.8)\end{array}$ & $\begin{array}{l}18.9 \\
(8.4)\end{array}$ & $\begin{array}{l}18.5 \\
(10)\end{array}$ \\
\hline $\mathrm{K}^{+}(\mathrm{mg} / \mathrm{L})$ & --- & $\begin{array}{l}3.80 \\
(4.3)\end{array}$ & $\begin{array}{l}32.6 \\
(51)\end{array}$ & $\begin{array}{l}21.8 \\
(31)\end{array}$ & $\begin{array}{c}2.15 \\
(0.39)\end{array}$ & $\begin{array}{c}2.02 \\
(0.30)\end{array}$ & $\begin{array}{c}1.40 \\
(0.50)\end{array}$ & $\begin{array}{c}3.37 \\
(0.82)\end{array}$ & $\begin{array}{c}4.0 \\
(1.2)\end{array}$ \\
\hline $\mathrm{Mg}^{2+}(\mathrm{mg} / \mathrm{L})$ & --- & $\begin{array}{l}1.08 \\
(2.3)\end{array}$ & $\begin{array}{l}5.18 \\
(5.3)\end{array}$ & $\begin{array}{l}2.69 \\
(1.7)\end{array}$ & $\begin{array}{l}23.8 \\
(2.6)\end{array}$ & $\begin{array}{l}23.0 \\
(1.8)\end{array}$ & $\begin{array}{l}23.4 \\
(3.0)\end{array}$ & $\begin{array}{l}30.6 \\
(3.3)\end{array}$ & $\begin{array}{l}31.0 \\
(1.9)\end{array}$ \\
\hline $\mathrm{Ca}^{2+}(\mathrm{mg} / \mathrm{L})$ & --- & $\begin{array}{l}3.45 \\
(3.1)\end{array}$ & $\begin{array}{l}17.0 \\
(16)\end{array}$ & $\begin{array}{l}8.62 \\
(4.9)\end{array}$ & $\begin{array}{l}84.3 \\
(8.9)\end{array}$ & $\begin{array}{l}80.4 \\
(4.8)\end{array}$ & $\begin{array}{l}78.6 \\
(8.4)\end{array}$ & $\begin{array}{l}99.8 \\
(12)\end{array}$ & $\begin{array}{c}111.2 \\
(5.3)\end{array}$ \\
\hline $\mathrm{Fe}_{\text {Total }}(\mu \mathrm{g} / \mathrm{L})$ & --- & --- & --- & --- & $\begin{array}{c}215 \\
(106)\end{array}$ & $\begin{array}{c}633 \\
(1056)\end{array}$ & $\begin{array}{l}179 \\
(67)\end{array}$ & $\begin{array}{c}2030 \\
(1720)\end{array}$ & $\begin{array}{r}1110 \\
(1550)\end{array}$ \\
\hline $\mathrm{Mn}^{2+}(\mu \mathrm{g} / \mathrm{L})$ & --- & --- & --- & --- & $\begin{array}{c}211 \\
(134)\end{array}$ & $\begin{array}{c}289 \\
(263)\end{array}$ & $\begin{array}{c}284 \\
(203)\end{array}$ & $\begin{array}{l}1090 \\
(794)\end{array}$ & $\begin{array}{r}3160 \\
(1737)\end{array}$ \\
\hline$A l^{3+}(\mu \mathrm{g} / \mathrm{L})$ & --- & --- & --- & --- & $\begin{array}{c}2.3 \\
(3.8)\end{array}$ & $\begin{array}{l}0.87 \\
(1.3)\end{array}$ & $\begin{array}{c}2.1 \\
(3.4)\end{array}$ & $\begin{array}{c}1.1 \\
(1.6)\end{array}$ & $\begin{array}{c}1.3 \\
(1.5)\end{array}$ \\
\hline \multicolumn{10}{|l|}{ lowa } \\
\hline$n$ & 7 & 5 & 13 & 15 & --- & --- & --- & --- & --- \\
\hline $\mathrm{Na}^{+}(\mathrm{mg} / \mathrm{L})$ & $\begin{array}{l}0.672 \\
(0.86)\end{array}$ & $\begin{array}{l}0.497 \\
(0.41)\end{array}$ & $\begin{array}{l}4.70 \\
(6.0)\end{array}$ & $\begin{array}{l}4.74 \\
(3.2)\end{array}$ & --- & --- & --- & --- & --- \\
\hline $\mathrm{K}^{+}$(mg/L) & $\begin{array}{l}1.70 \\
(3.1)\end{array}$ & $\begin{array}{l}0.396 \\
(0.21)\end{array}$ & $\begin{array}{l}2.32 \\
(3.6)\end{array}$ & $\begin{array}{l}2.55 \\
(7.8)\end{array}$ & --- & --- & --- & --- & --- \\
\hline $\mathrm{Mg}^{2+}(\mathrm{mg} / \mathrm{L})$ & $\begin{array}{l}0.421 \\
(0.41)\end{array}$ & $\begin{array}{l}0.571 \\
(0.40)\end{array}$ & $\begin{array}{l}6.73 \\
(2.8)\end{array}$ & $\begin{array}{l}1.87 \\
(1.1)\end{array}$ & --- & --- & --- & --- & --- \\
\hline $\mathrm{Ca}^{2+}(\mathrm{mg} / \mathrm{L})$ & $\begin{array}{l}2.38 \\
(1.0)\end{array}$ & $\begin{array}{l}1.75 \\
(1.5)\end{array}$ & $\begin{array}{l}24.9 \\
(12)\end{array}$ & $\begin{array}{l}6.70 \\
(4.4)\end{array}$ & --- & --- & --- & --- & --- \\
\hline
\end{tabular}

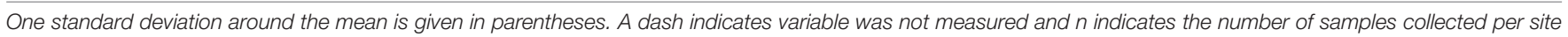
for each sample type.

\section{Geochemical Fluxes}

For $\mathrm{Ca}^{2+}$ and $\mathrm{Mg}^{2+}$ in the pore waters, the likely control on concentration is the dissolution of carbonates. The speciation calculations showed undersaturation with respect to both calcite and dolomite under both land uses at both study sites, implying a kinetic control on dissolution (Table 5). Based on the $\mathrm{pH}$ and the activities of the carbonate aqueous species in the pore water samples, the calcite dissolution rate would be expected to be about $6 \%$ faster in the prairie soils compared to the agricultural soils in Nebraska and $8 \%$ faster in Iowa (Plummer et al., 1978). However, at both locations, the saturation index for calcite was more negative in the prairie soils suggesting less calcite has dissolved compared to the agricultural soil. Since chemical equilibrium was not attained, and the calculated rates of dissolution do not match the amount of dissolution observed, the control on carbonate solubility is likely not a chemical constraint. Instead, it is more likely a hydrological constraint where the pore water under agriculture is moving more slowly and has more time to interact with the soil matrix thereby moving slightly closer to equilibrium despite slower kinetics (Jin et al., 2008). The same saturation state relationships were also seen for dolomite.
In the Nebraska soils, the differences in the saturation indices were smaller than those in Iowa, yet the calculated $\mathrm{P}_{\mathrm{CO} 2}$ was noticeably higher in prairie soils (Table 5). Since the $\mathrm{CO}_{2}$ in the pore space from mineral sources was at least similar between agriculture and prairie soils at each site, the larger $\mathrm{P}_{\mathrm{CO} 2}$ is likely due to more biological respiration occurring in the prairie soils (Raich and Tufekcioglu, 2000). Despite the increased $\mathrm{P}_{\mathrm{CO} 2}$ and decreased $\mathrm{pH}$ in prairie soil from respiration leading to the expected faster dissolution rate, the rate of water drainage appears to more strongly affect the total amount of carbonate dissolution in the two soils (Egli and Fitze, 2001). However, unlike the Nebraska soils, there was a much larger difference between the agricultural and prairie saturation indices in Iowa, and the $\mathrm{P}_{\mathrm{CO} 2}$ was larger in the agricultural soils. In this case, the larger $\mathrm{P}_{\mathrm{CO} 2}$ in agriculture is more likely driven by either the larger amounts of carbonate dissolution or by the distinct soil types associated with the Iowa site in Nebraska, discussed below. Between the pore water samplers and the stream, conditions shift such that in both the prairie and agricultural setting, the carbonates are essentially at equilibrium and are controlling $\mathrm{Ca}^{2+}$ and $\mathrm{Mg}^{2+}$ fluxes.

Relative to the pore waters, stream water elemental fluxes appear to be driven by flow. Even though the concentrations 


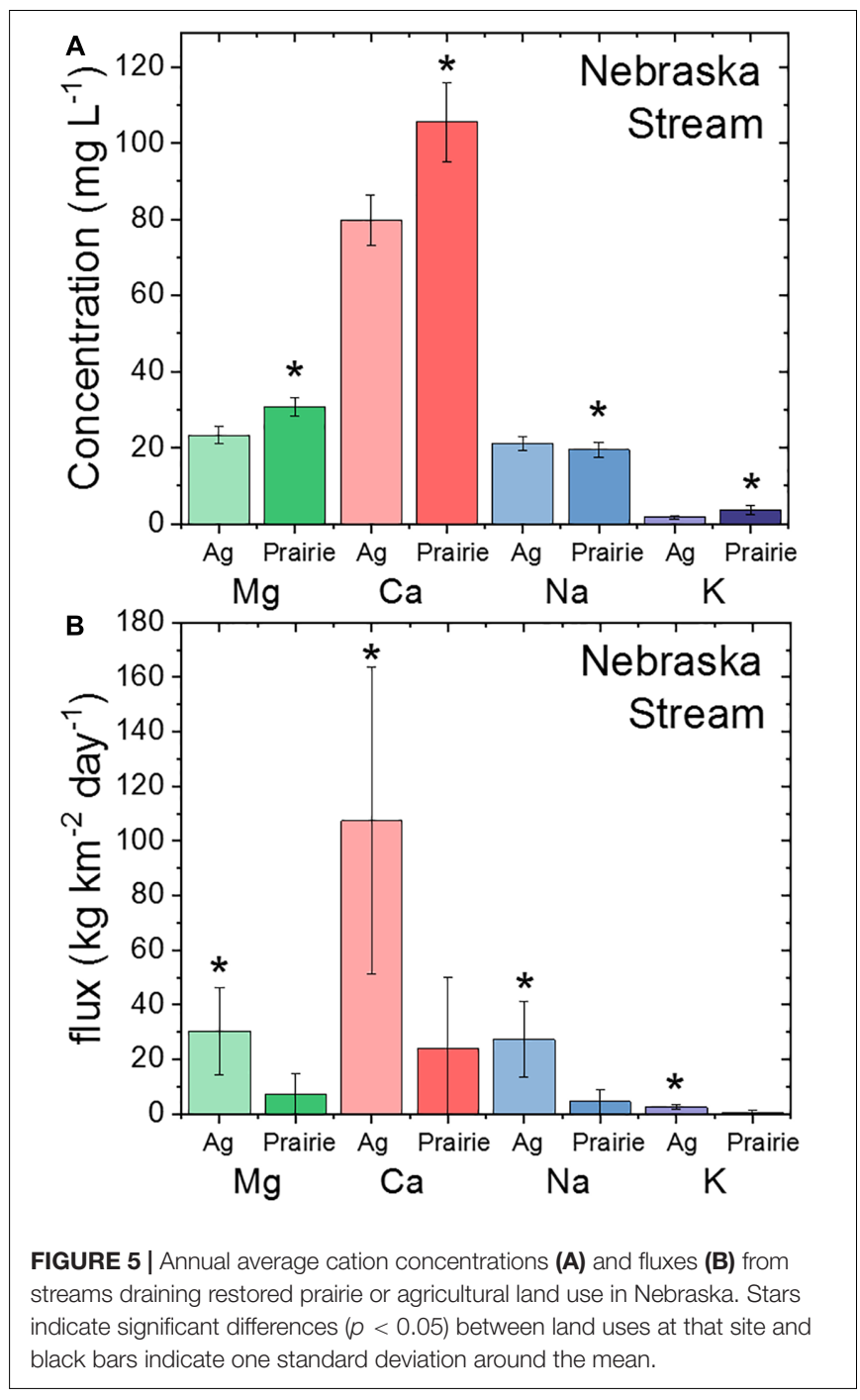

of $\mathrm{Ca}^{2+}$ and $\mathrm{Mg}^{2+}$ were higher in the stretches associated with the prairie in Nebraska, the much higher flow rate from the agricultural setting led to larger elemental fluxes associated with agriculture. Similar relationships have been widely observed, for example by Godsey et al. (2009) who analyzed weatheringderived solutes $(\mathrm{Si}, \mathrm{Ca}$, and $\mathrm{Mg}$ ) in 59 watersheds and showed that solute fluxes were proportional to discharge. Pore water fluxes are more typically concentration driven. Extractable pore water volumes under both land uses were at least comparable, such that larger concentrations under agriculture also led to larger fluxes.

Although no stream water was routinely sampled for solute chemistry in Iowa, two grab samples from Clear Creek near the agricultural study site were collected in June 2015 and December 2016 (westernmost triangle in Figure 1D). Average concentrations from these two collection dates were $26.5 \pm 0.38 \mathrm{mg} \mathrm{L}^{-1}$ of $\mathrm{Mg}^{2+}, 58 \pm 22 \mathrm{mg} \mathrm{L}^{-1}$ of $\mathrm{Ca}^{2+}$, $7.8 \pm 1.0 \mathrm{mg} \mathrm{L}^{-1}$ of $\mathrm{Na}^{+}$, and $0.73 \pm 0.12 \mathrm{mg} \mathrm{L}^{-1}$ of $\mathrm{K}^{+}$, values that are similar in magnitude to concentrations measured in the Nebraska stream. Although there is no stream draining prairie in Iowa to compare cation concentrations, the Iowa stream draining agriculture appears to have similarly high concentrations of $\mathrm{Ca}^{2+}$ and $\mathrm{Mg}^{2+}$ relative to $\mathrm{Na}^{+}$and $\mathrm{K}^{+}$.

\section{Hydrologic Connectivity}

From the chemical and data analysis, interpretations of hydrologic flowpaths can be made. From the pore water analysis, it appears that water drains more slowly within the top $1 \mathrm{~m}$ of the agricultural soil compared to the prairie soils, which caused the water chemistry to move closer to equilibrium with respect to calcite and dolomite in agricultural soils. The larger drainage rate under the prairie soils is consistent with other work showing that more deeply rooted prairie perennials make better connections between pore spaces in the soil than do the annual plants planted in agricultural settings (Udawatta et al., 2008). However, comparing the relative stream concentrations to the pore water concentrations implies a disconnect under the agricultural setting. Despite the higher relative concentrations in the agricultural pore waters, the relative stream concentrations were lower, implying a second water source that does not interact with the soils thereby diluting the stream concentrations. A likely interpretation is that some amount of the precipitation that falls on the agricultural soils does not infiltrate, but instead runs off more directly to the stream (Schilling et al., 2008). Furthermore, $\mathrm{Cl}^{-}$concentrations were roughly four times lower in agricultural stream water compared to the soil pore water, suggesting possible preferential flowpaths contributing to the agricultural stream (Table 4) (Aubert et al., 2013). The high soil pore water $\mathrm{Cl}^{-}$ concentrations, although extremely variable, may also point to longer residence time for shallow water in the agricultural soils compared to prairie soils (Kirchner et al., 2010).

Under the prairie setting in Nebraska, there was no evidence of increased runoff, and precipitation instead infiltrates rapidly through the upper $50 \mathrm{~cm}$ of the soil profile, resulting in overall lower soil moisture than the agricultural soil that receives the same amount of precipitation (Figure 3A). Furthermore, prairie soil moisture increased at all depths in response to precipitation events, especially in the fall when grasses have senesced (Figure 2A). In contrast, a study by Masarik et al. (2014) on similar silty loess soils and climate to our study reported higher soil matric potential measurements in prairie soils compared to agricultural soils, indicating prairie soils did not dry out as much as soils planted with corn, and overall drainage through restored prairie soils was $57-69 \%$ lower than agriculture soils. The authors attributed this difference to the ability of perennial grass vegetation with established root networks to take up water earlier in the season and later into the year than corn vegetation. Although it is likely that differences in water use between crops and prairie grasses exist at our sites, the differences we observed in soil moisture and EC persisted even in fall after crops were removed and grasses senesced, so moisture removal by prairie vegetation is not likely to entirely explain the different patterns in soil moisture and EC.

In contrast, average soil moisture at the Iowa study site was greater in prairie soils at all depths compared to agricultural soils (Figure 3B). This is likely due to differences in soil genesis between these sites: the restored prairie site was forested prior 
TABLE 3 | Average daily solute fluxes for stream and pore water in Nebraska (NE) and lowa (IA) agriculture or restored prairie land use.

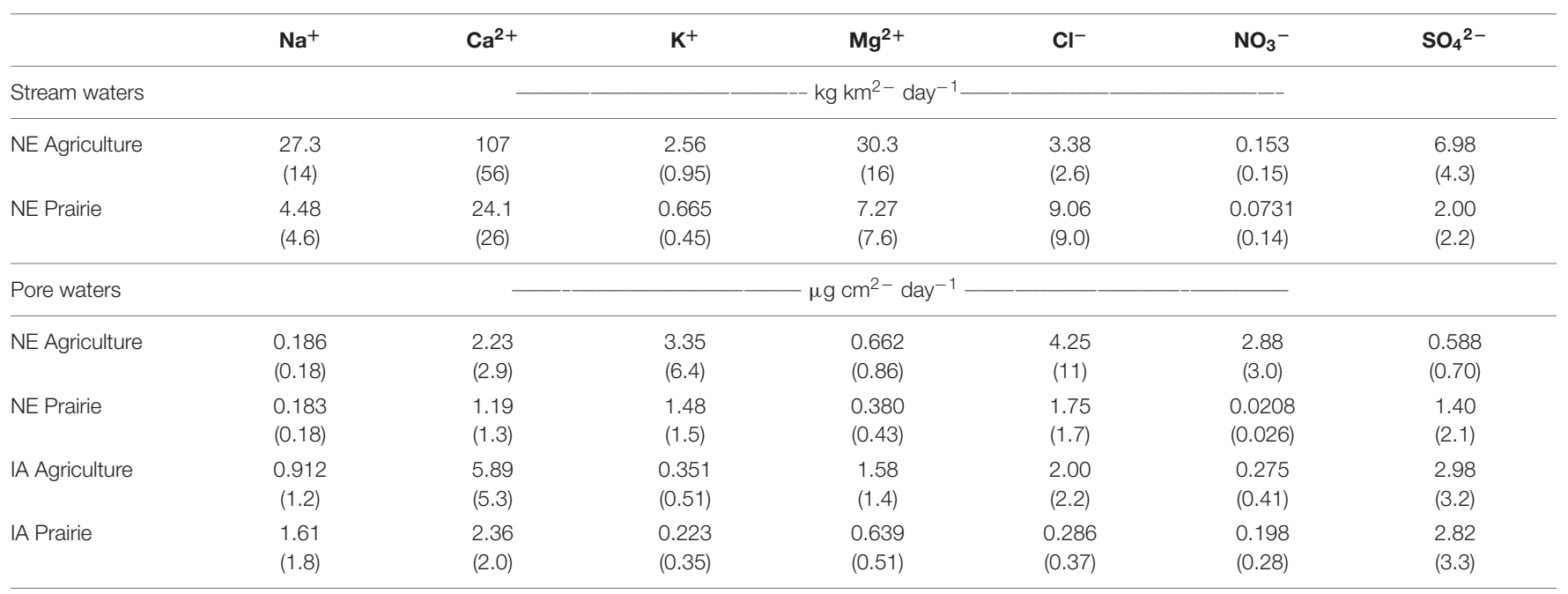

One standard deviation around the mean is given in parentheses.
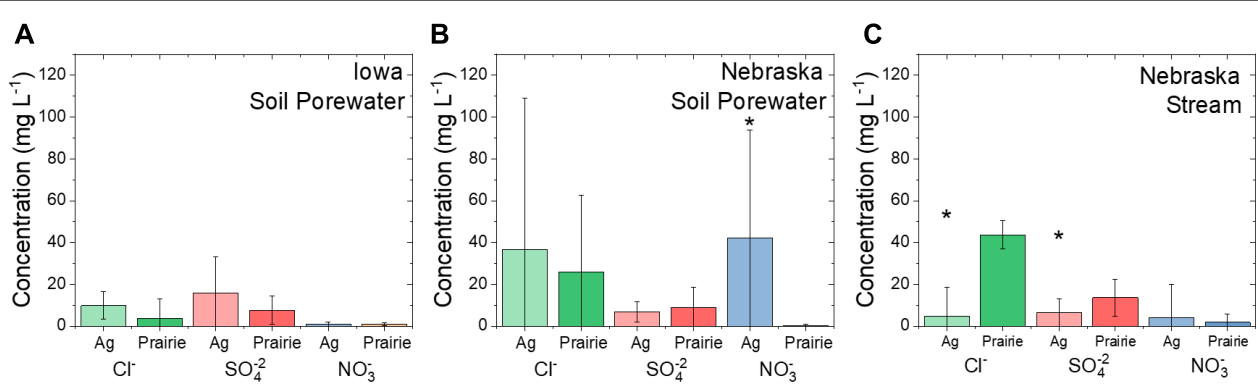

FIGURE 6 | Average annual soil pore water anion concentrations at the lowa (A) and Nebraska (B) study sites and annual average stream water anion concentrations at the Nebraska study site (C) for both agriculture and restored prairie land use. Stars indicate significant differences $(p<0.05)$ between land uses at that site and black bars indicate one standard deviation around the mean.

to cultivation, which led to the formation of Alfisols, a soil that typically forms under hardwood forest in humid areas and is characterized by clay-enriched subsoil and relatively thin accumulations of organic matter (Soil Survey Staff, 1999). In contrast, the agricultural site hosted tallgrass prairie prior to cultivation, which resulted in the formation of Mollisols, or soils characterized by high organic matter accumulation (Soil Survey Staff, 1999). Clay content was overall slightly higher in the restored prairie soil $(\sim 26 \%$ clay in the upper $50 \mathrm{~cm})$ compared to the agricultural site $(\sim 22 \%$ clay in the upper $50 \mathrm{~cm})$, perhaps as a result of the soil previously forming under forest vegetation rather than prairie vegetation. Water retention is greater for clay-sized soil particles (Saxton and Rawls, 2006), which could account for the higher moisture content in the more clay-rich restored prairie soil. However, despite the different soil forming conditions prior to cultivation between the Iowa restored prairie and agricultural soils, the patterns with respect to soil pore water chemistry were similar to observations at the Nebraska site.

There was evidence in the Nebraska prairie of water interactions with mineral phases much deeper in the subsurface. At the stream sampling locations draining prairie (G5 and
G6 in Figure 1C), the concentration of the redox active $\mathrm{Fe}^{2+/ 3+}$ and $\mathrm{Mn}^{2+}$ were significantly higher than found in the stream draining agriculture (G3 and G4 in Figure 1C). Further, large amounts of iron flocs were consistently present in the prairie sampling locations, and they were not present at the agricultural locations, despite similar ranges of saturation indices for ferrihydrite [prairie saturation index (SI) range: 1.61-2.79, agriculture SI range: 0.16-2.28]. The larger concentrations of the redox active metals suggests a water source that is separated from the atmosphere. For all four stream sampling locations in Nebraska, the effective $\mathrm{P}_{\mathrm{CO} 2}$ was also much higher than equilibrium with the atmosphere $(\mathrm{GC} 3=3.8 \mathrm{E}-2, \mathrm{GC} 4=2.6 \mathrm{E}-2$, GC5 $=2.3 \mathrm{E}-2$, GC6 $=6.0 \mathrm{E}-2$, atmospheric $\mathrm{P}_{\mathrm{CO} 2}=\sim 4 \mathrm{E}-4$, all values in atm). The highest value was at position GC6 in the prairie, which again implies a water source that is separated from the atmosphere. Between GC6 and GC5, there is a small cascade where $\mathrm{CO}_{2}$ is likely being lost. The stream section connecting GC4 (upstream) to GC3 (downstream) is quite flat so de-gassing is at a minimum. The stream $\mathrm{P}_{\mathrm{CO} 2}$ values are essentially the same order of magnitude as values found in groundwater associated with limestone host rock (Macpherson et al., 2008). 


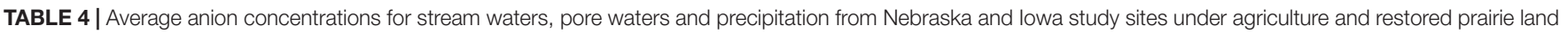
use.

\begin{tabular}{|c|c|c|c|c|c|c|c|c|c|}
\hline \multirow[b]{3}{*}{ Ion } & \multicolumn{2}{|c|}{ Precipitation } & \multicolumn{2}{|c|}{ Pore water } & \multicolumn{5}{|c|}{ Stream water } \\
\hline & \multirow[t]{2}{*}{ Agriculture } & \multirow[t]{2}{*}{ Prairie } & \multirow[t]{2}{*}{ Agriculture } & \multirow[t]{2}{*}{ Prairie } & \multirow[b]{2}{*}{ GC2 } & \multicolumn{2}{|c|}{ Agriculture } & \multicolumn{2}{|c|}{ Prairie } \\
\hline & & & & & & GC3 & GC4 & GC5 & GC6 \\
\hline \multicolumn{10}{|l|}{ Nebraska } \\
\hline$N$ & --- & 6 & 34 & 36 & 10 & 10 & 11 & 11 & 10 \\
\hline $\mathrm{Cl}^{-}(\mathrm{mg} / \mathrm{L})$ & --- & $\begin{array}{l}2.98 \\
(2.6)\end{array}$ & $\begin{array}{l}36.7 \\
(72)\end{array}$ & $\begin{array}{l}25.8 \\
(37)\end{array}$ & $\begin{array}{l}9.06 \\
(5.7)\end{array}$ & $\begin{array}{l}8.17 \\
(20)\end{array}$ & $\begin{array}{c}1.17 \\
(0.53)\end{array}$ & $\begin{array}{l}39.6 \\
(5.1)\end{array}$ & $\begin{array}{l}47.3 \\
(5.6)\end{array}$ \\
\hline $\mathrm{NO}_{2}-(\mathrm{mg} / \mathrm{L})$ & --- & $\begin{array}{l}0.0708 \\
(0.028)\end{array}$ & $\begin{array}{l}0.207 \\
(0.28)\end{array}$ & $\begin{array}{l}0.0609 \\
(0.092)\end{array}$ & $\begin{array}{c}0.017 \\
(0.006)\end{array}$ & $\begin{array}{c}0.024 \\
(0.016)\end{array}$ & $\begin{array}{c}0.020 \\
(0.004)\end{array}$ & $\begin{array}{c}0.017 \\
(0.017)\end{array}$ & $\begin{array}{l}4.38 \\
(6.3)\end{array}$ \\
\hline $\mathrm{NO}_{3}^{-}(\mathrm{mg} / \mathrm{L})$ & --- & $\begin{array}{l}3.06 \\
(3.5)\end{array}$ & $\begin{array}{l}42.3 \\
(51)\end{array}$ & $\begin{array}{l}0.321 \\
(0.56)\end{array}$ & $\begin{array}{l}3.18 \\
(2.1)\end{array}$ & $\begin{array}{l}0.266 \\
(0.45)\end{array}$ & $\begin{array}{l}0.724 \\
(0.84)\end{array}$ & $\begin{array}{l}0.412 \\
(0.53)\end{array}$ & $\begin{array}{l}4.38 \\
(6.3)\end{array}$ \\
\hline $\mathrm{SO}_{4}^{2-}(\mathrm{mg} / \mathrm{L})$ & --- & $\begin{array}{l}1.74 \\
(2.1)\end{array}$ & $\begin{array}{l}6.86 \\
(4.8)\end{array}$ & $\begin{array}{l}8.92 \\
(9.6)\end{array}$ & $\begin{array}{l}8.42 \\
(3.1)\end{array}$ & $\begin{array}{l}7.18 \\
(7.0)\end{array}$ & $\begin{array}{l}5.81 \\
(6.6)\end{array}$ & $\begin{array}{c}9.89 \\
(11.3)\end{array}$ & $\begin{array}{l}17.2 \\
(3.7)\end{array}$ \\
\hline $\mathrm{PO}_{4}^{3-}(\mathrm{mg} / \mathrm{L})$ & --- & $\begin{array}{c}0.0156 \\
(0.17)\end{array}$ & $\begin{array}{l}0.368 \\
(0.82)\end{array}$ & $\begin{array}{l}0.298 \\
(0.71)\end{array}$ & $\begin{array}{c}0.089 \\
(0.018)\end{array}$ & $\begin{array}{c}0.113 \\
(0.059)\end{array}$ & $\begin{array}{c}0.069 \\
(0.027)\end{array}$ & ND & $\begin{array}{c}0.063 \\
(0.062)\end{array}$ \\
\hline Alkalinity (mg/L as $\mathrm{CaCO}_{3}$ ) & --- & --- & $\begin{array}{l}14.7 \\
(7.9)\end{array}$ & $\begin{array}{l}20.5 \\
(10)\end{array}$ & $\begin{array}{l}354 \\
(18)\end{array}$ & $\begin{array}{l}355 \\
(18)\end{array}$ & $\begin{array}{l}355 \\
(24)\end{array}$ & $\begin{array}{l}390 \\
(24)\end{array}$ & $\begin{array}{l}413 \\
(30)\end{array}$ \\
\hline \multicolumn{10}{|l|}{ lowa } \\
\hline$n$ & 8 & 7 & 14 & 16 & --- & --- & --- & --- & --- \\
\hline $\mathrm{Cl}^{-}(\mathrm{mg} / \mathrm{L})$ & $\begin{array}{l}0.730 \\
(0.62)\end{array}$ & $\begin{array}{l}0.748 \\
(0.44)\end{array}$ & $\begin{array}{l}9.74 \\
(6.6)\end{array}$ & $\begin{array}{l}3.76 \\
(9.1)\end{array}$ & --- & --- & --- & --- & --- \\
\hline $\mathrm{NO}_{2}^{-}(\mathrm{mg} / \mathrm{L})$ & $\begin{array}{l}0.0546 \\
(0.045)\end{array}$ & $\begin{array}{c}0.518 \\
(1.1)\end{array}$ & $\begin{array}{c}0.032 \\
(0.027)\end{array}$ & $\begin{array}{l}0.169 \\
(0.23)\end{array}$ & --- & --- & --- & --- & --- \\
\hline $\mathrm{NO}_{3}-(\mathrm{mg} / \mathrm{L})$ & $\begin{array}{l}1.16 \\
(0.55)\end{array}$ & $\begin{array}{c}0.518 \\
(1.1)\end{array}$ & $\begin{array}{c}0.922 \\
(1.0)\end{array}$ & $\begin{array}{l}0.968 \\
(0.76)\end{array}$ & --- & --- & --- & --- & --- \\
\hline $\mathrm{SO}_{4}^{2-}(\mathrm{mg} / \mathrm{L})$ & $\begin{array}{c}1.15 \\
(0.41)\end{array}$ & $\begin{array}{c}1.87 \\
(2.09)\end{array}$ & $\begin{array}{l}15.8 \\
(17)\end{array}$ & $\begin{array}{l}7.52 \\
(6.8)\end{array}$ & --- & --- & --- & --- & --- \\
\hline $\mathrm{PO}_{4}{ }^{3-}(\mathrm{mg} / \mathrm{L})$ & $\begin{array}{l}1.42 \\
(1.9)\end{array}$ & $\begin{array}{l}0.639 \\
(0.82)\end{array}$ & $\begin{array}{l}1.42 \\
(2.0)\end{array}$ & $\begin{array}{l}0.193 \\
(0.25)\end{array}$ & --- & --- & --- & --- & --- \\
\hline Alkalinity (mg/L as $\mathrm{CaCO}_{3}$ ) & $\begin{array}{l}12.0 \\
(5.7)\end{array}$ & $\begin{array}{l}17.1 \\
(6.5)\end{array}$ & $\begin{array}{c}88.8 \\
(33)\end{array}$ & $\begin{array}{c}32.3 \\
(16)\end{array}$ & --- & --- & --- & --- & --- \\
\hline
\end{tabular}

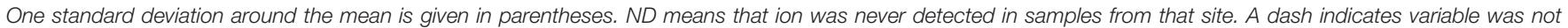
measured and $n$ indicates the number of samples collected per site for each sample type.

\section{Conceptual Model}

The observations reported here lead to a conceptual model whereby agricultural land use has altered soil hydrology, and in turn soil chemistry, and those alterations were propagated to changes in nearby stream chemistry. Precipitation appears to infiltrate agricultural soils slowly, allowing more time for mineral-water interaction (Figure 7). The agricultural soil waters were enriched in ions, especially $\mathrm{Ca}^{2+}$ and $\mathrm{Mg}^{2+}$, but rather than flushing the dissolved solutes deeper into the soil profile, the solutes appear to be routed rapidly to the nearby stream where they influence stream chemistry. In contrast, precipitation entering a soil dominated by prairie vegetation appears to infiltrate rapidly, limiting time for mineral-water interactions near the surface. Thus, soil pore water chemistry more closely resembles dilute precipitation and infiltrates deeper into the soil before entering the stream.

A likely explanation for differences in hydrology between agriculture and restored prairie, and in turn the soil water chemistry, is reduced pore connectivity in agricultural systems due to limited rooting depths and densities of corn and soybean
TABLE 5 | Water chemistry measured and calculated values for stream and pore waters in Nebraska (NE) and lowa (IA) agriculture or restored prairie land use.

$\begin{array}{ccccc}\text { pH } & \text { Alkalinity (mg } & \text { Pco2 } & \text { Calcite } & \text { Dolomit } \\ \text { L }^{-1} \text { as } & (\text { atm) } & \text { SI } & \text { SI } \\ \text { CaCO-3) } & & & \end{array}$

\begin{tabular}{|c|c|c|c|c|c|}
\hline \multicolumn{6}{|l|}{ Stream waters } \\
\hline NE Agriculture & $7.06(0.2)$ & $355(21)$ & $3.2 \mathrm{E}-2$ & -0.035 & -0.31 \\
\hline NE Prairie & $6.94(0.3)$ & $402(30)$ & 4.1E-2 & 0.12 & 0.058 \\
\hline \multicolumn{6}{|l|}{ Pore waters } \\
\hline NE Agriculture & $6.83(0.4)$ & $14.7(7.9)$ & $1.2 \mathrm{E}-3$ & -2.6 & -4.6 \\
\hline NE Prairie & $6.59(0.7)$ & $20.5(10)$ & 4.3E-3 & -2.8 & -5.8 \\
\hline IA Agriculture & $7.04(0.6)$ & $88.8(33)$ & 5.9E-3 & -0.79 & -1.9 \\
\hline IA Prairie & $7.24(0.3)$ & $32.3(16)$ & $2.9 \mathrm{E}-3$ & -2.1 & -4.4 \\
\hline
\end{tabular}

For directly measured values, one standard deviation around the mean is given in parentheses, all other values were calculated in PHREEQC.

crops as well as compaction by agricultural equipment that destroys soil structure. Prairie systems, however, are known for extensive and deep root networks (Jackson et al., 1996) that create 


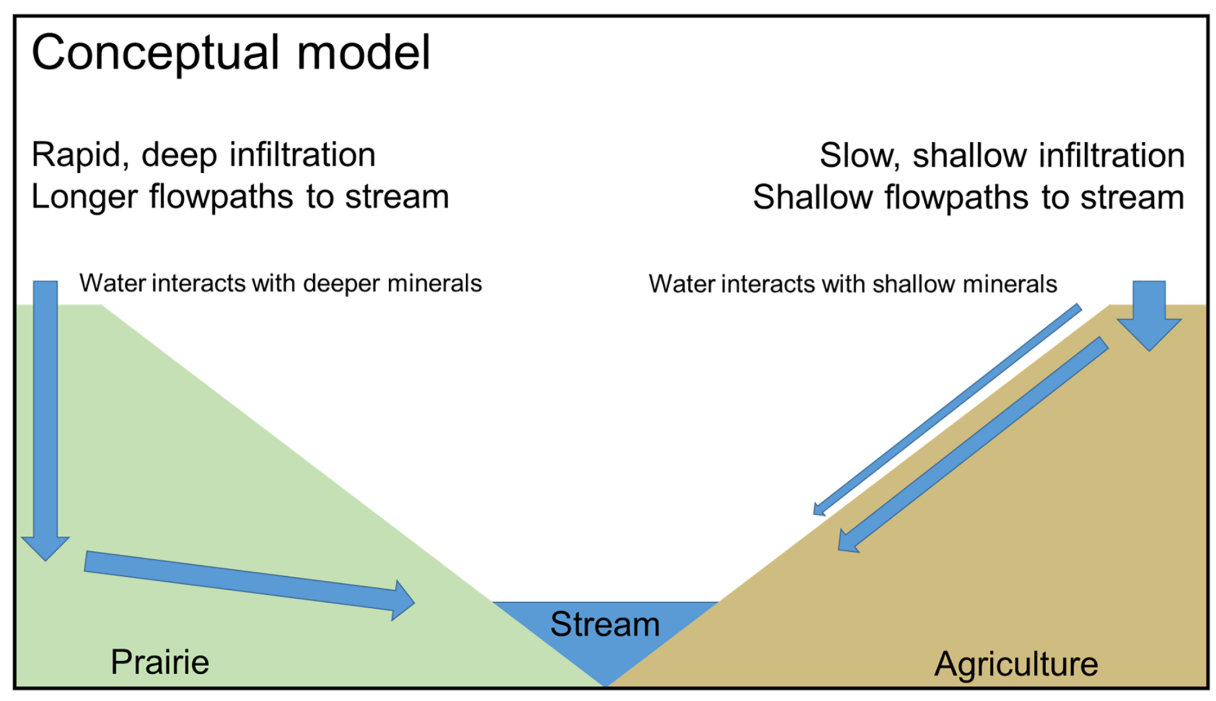

FIGURE 7 | Conceptual model of hydrologic fluxes influencing soil and stream chemistry in intensively managed landscapes.

preferential flowpath and enhance soil aggregation (Udawatta et al., 2008), providing pathways for water and oxygen to infiltrate more deeply into the soil. Directly quantifying differences in pore networks is a logical future step for investigating hydrologic and geochemical connectivity in these intensively managed systems.

Furthermore, an intriguing observation is the relatively short time needed to observe differences in soil hydrology and chemistry between land uses. In Nebraska, both soil sampling locations were farmed until roughly 50 years ago when agriculture ceased in one part of the watershed. In Iowa, the site was farmed until 20 years ago. Thus, the changes in pore connectivity and hydrologic fluxes have been realized in just a few decades, and the influence on soil and stream chemistry is already distinguishable. Such results point to a highly dynamic system that can be influenced by land use not just at the surface, where direct management occurs, but deeper into the critical zone and ultimately into streams.

\section{CONCLUSION}

Clear chemical differences in both the pore and stream waters were detected under two land uses (row crop agriculture and restored prairie) at two study sites (Nebraska and Iowa) that are representative of the Midwestern USA region. Similarly, clear differences were observed between soil moisture and EC under the two land uses. From these differences we constructed a conceptual model describing likely hydrological processes within the $\mathrm{CZ}$ at the Nebraska field site. It appears that within just a few decades, restored prairie can re-establish much of the deeper pore connectivity that tends to be destroyed under agriculture. The restoration of connectivity leads to alterations of soil and mineral weathering patterns within the pore spaces of the soil. The altered dissolution of the minerals based on surficial land use is transferred downslope as the pore waters drain into the connected stream. Under prairie land use, it appears that this draining is likely direct, proceeding downward to the impermeable till and surfacing in the stream. Under agriculture land use, the draining of pore water is likely indirect, with the water perching in the shallow sub-surface before flowing with associated runoff into the connected stream. Future research will focus on identifying the mechanisms driving contrasting hydrologic and geochemical behavior between land use types.

\section{DATA AVAILABILITY STATEMENT}

The meteorological, soil sensor, and discharge datasets generated from this study can be found in the EarthChem Library (http://earthchem.org/library).

\section{AUTHOR CONTRIBUTIONS}

$\mathrm{AD}, \mathrm{AM}$, and $\mathrm{EB}$ conceptualized the research. $\mathrm{AD}, \mathrm{AM}, \mathrm{EB}$, SP, CC, and AH collected and processed samples. AM and AH completed laboratory analysis and speciation calculations. AD, $\mathrm{AM}$, and $\mathrm{EB}$ analyzed the data. $\mathrm{AD}, \mathrm{AM}$, and $\mathrm{EB}$ prepared the manuscript.

\section{FUNDING}

This work was supported by NSF Grant EAR-1331906 for the Intensively Managed Landscapes Critical Zone Observatory (PI P. Kumar), Douglas County Environmental Services, the Sherwood Foundation Teacher-Researcher Partnership Program grant (ID \#5444), the University of Nebraska at Omaha University Committee on Research and Creative Activity (UCRCA), and the generous support of B. Hayes and T. Bragg at Glacier Creek Preserve. 


\section{ACKNOWLEDGMENTS}

We would like to thank the Maas Family and FW Kent State Park for supporting research on their properties, as well as Barbi Hayes and Tom Bragg for their support of research at Glacier Creek Preserve. We also thank Tracy Coleman for field instrumentation support at Glacier Creek Preserve, Chris Jackson for assistance collecting and analyzing samples, Katie Goff and Will Boyd for their help sampling Iowa sites, and Paul Hunt for assistance generating site maps. Additional field and laboratory assistance was provided by: R. Benzoni, R. Burns, M. Cain, D. Dere, J.

\section{REFERENCES}

Anders, A. M., Bettis, E. A. III, Grimley, D. A., Stumpf, A. J., and Kumar, P. (2018). Impacts of quaternary history on critical zone structure and processes: examples and a conceptual model from the intensively managed landscapes critical zone observatory. Front. Earth Sci. 6:24. doi: 10.3389/feart.2018. 00024

Aubert, A. H., Gascuel-Odoux, C., Gruau, G., Akkal, N., Faucheux, M., Fauvel, Y., et al. (2013). Solute transport dynamics in small, shallow groundwaterdominated agricultural catchments: insights from a high-frequency, multisolute 10 yr-long monitoring study. Hydrol. Earth Syst. Sci. 17, 1379-1391. doi: 10. 5194/hess-17-1379-2013

Banwart, S. (2011). Save our soils. Nature 474, 151-152. doi: 10.1038/474151a

Bettis, E. A. III, Muhs, D. R., Roberts, H. M., and Wintle, A. G. (2003). Last glacial loess in the conterminous USA. Quat. Sci. Rev. 22, 1907-1946. doi: 10.1016/S0277-3791(03)00169-0

Brantley, S. L., Goldhaber, M. B., and Ragnarsdottir, K. V. (2007). Crossing disciplines and scales to understand the critical zone. Elements 3, 307-314. doi: 10.2113/gselements.3.5.307

Davis, M. L., and Cornwell, D. A. (1998). Introduction to Environmental Engineering, 3rd Edn. Boston, MA: McGraw-Hill.

Egli, M., and Fitze, P. (2001). Quantitative aspects of carbonate leaching of soils with differing ages and climates. Catena 46, 35-62. doi: 10.1016/S0341-8162(01) 00154-0

Foley, J. A., DeFries, R., Asner, G. P., Barford, C., Bonan, G., Carpenter, S. R., et al. (2005). Global consequences of land use. Science 309, 570-574. doi: 10.1126/ science. 1111772

Godsey, S. E., Kirchner, J. W., and Clow, D. W. (2009). Concentration-discharge relationships reflect chemostatic characteristics of US catchments. Hydrol. Process. 23, 1844-1864. doi: 10.1002/hyp.7315

Hinckley, E.-L. S., Barnes, R. T., Anderson, S. P., Williams, M. W., and Bernasconi, S. M. (2014). Nitrogen retention and transport differ by hillslope aspect at the rain-snow transition of the colorado front range. J. Geophys. Res. Biogeo. 119, 1281-1296. doi: 10.1002/2013JGE002588

Jackson, R. B., Canadell, J., Ehleringer, J. R., Moonery, H. A., Sala, O. E., and Schulze, E. D. A. (1996). Global analysis of root distributions for terrestrial biomes. Oecologia 108, 389-411. doi: 10.1007/BF00333714

Jin, L., Andrews, D. M., Holmes, G. H., Lin, H., and Brantley, S. L. (2011). Opening the "Black Box": water chemistry reveals hydrological controls on weathering in the susquehanna shale hills critical zone observatory. Vadose Zone J. 10, 928-942. doi: 10.2136/vzj2010.0133

Jin, L., Williams, E. L., Szramek, K. J., Walter, L. M., and Hamilton, S. K. (2008). Silicate and carbonate mineral weathering in soil profiles developed on pleistocene glacial drift (Michigan, USA): mass balances based on soil water geochemistry. Geochim. Cosmochim. Acta 72, 1027-1042. doi: 10.1016/j.gca. 2007.12.007

Kirchner, J. W., Tetzlaff, D., and Soulsby, C. (2010). Comparing chloride and water isotopes as hydrological tracers in two Scottish catchments. Hydrol. Process. 24, 1631-1645. doi: 10.1002/hyp.7676

Kumar, P., Le, P. V. V., Papanicolaou, A. N., Rhoads, B. L., Anders, A. M., Stumpf, A., et al. (2018). Critical transition in critical zone of intensively managed landscapes. Anthropocene 22, 10-19. doi: 10.1016/j.ancene.2018. 04.002
Felix, T. Frederick, K. Gerdes, B. Greco, L. LeGrand, D. Klein, K. Knapp, J. Lopez, S. Nath, M. O’Malley, S. Rodie, S. Sterner, L. Stover, B. Terrell, and T. Webb. We also greatly appreciate the insightful suggestions provided by the reviewers.

\section{SUPPLEMENTARY MATERIAL}

The Supplementary Material for this article can be found online at: https://www.frontiersin.org/articles/10.3389/feart. 2019.00024/full\#supplementary-material

Macpherson, G. L., Roberts, J. A., Blair, J. M., Townsend, M. A., Fowle, D. A., and Beisner, K. R. (2008). Increasing shallow groundwater CO2 and limestone weathering, Konz Prairie, USA. Geochim. Cosmochim. Acta 72, 5581-5599. doi: 10.1016/j.gca.2008.09.004

Masarik, K. C., Norman, J. M., and Brye, K. R. (2014). Long-term drainage and nitrate leaching below well-drained continuous corn agroecosystems and a prairie. J. Environ. Protect. 5, 240-254. doi: 10.4236/jep.2014. 54028

Neal, C. W. M., and Anders, A. M. (2015). Suspended sediment supply dominated by bank erosion in a low-gradient agricultural watershed, Wildcat Slough, Fisher, Illinois, United States. J. Soil Water Conserv. 70, 145-155. doi: 10.2489/ jswc.70.3.145

Papanicolaou, A. N., Abban, B. K., Dermisis, D. C., Giannopoulos, C. P., Flanagan, D. C., Frankenberger, J. R., et al. (2018). Flow resistance interactions on hillslopes with heterogeneous attributes: effects on runoff hydrograph characteristics. Water Resour. Res. 54, 359-380. doi: 10.1002/2017WR0 21109

Papanicolaou, A. N., Elhakeem, M., Wilson, C. G., Burras, C. L., West, L. T., Lin, H., et al. (2015a). Spatial variability of saturated hydraulic conductivity at the hillslope scale: understanding the role of land management and erosional effect. Geoderma 24, 58-68. doi: 10.1016/j.geoderma.2014.12.010

Papanicolaou, A. N., Wacha, K. M., Abban, B. K., Wilson, C. G., Hatfield, J. L., Stanier, C. O., et al. (2015b). From soilscapes to landscapes: a landscapeoriented approach to simulate soil organic carbon dynamics in intensively managed landscapes. J. Geophys. Res. Biogeo. 120, 2375-2401. doi: 10.1002/ 2015JG00.078

Papanicolaou, A. N. T., Wilson, C. G., Tsakiris, A. G., Sutarto, T. E., Bertrand, F., Rinaldi, M., et al. (2017). Understanding mass fluvial erosion along a bank profile: using PEEP technology for quantifying retreat lengths and identifying event timing. Earth Surf. Process. Landforms 42, 1717-1732. doi: 10.1002/esp. 4138

Parkhurst, D. L., and Appelo, C. A. J. (2013). Description of Input and Examples for PHREEQC Version 3-A Computer Program for Speciation, Batch-Reaction, One-dimensional Transport, and Inverse Geochemical Calculations. Available at: http://pubs.usgs.gov/tm/06/a43 [accessed August 27, 2018] doi: 10.3133/ tm6A43

Plummer, L. N., Wigley, T. M. L., and Parkhurst, D. L. (1978). The kinetics of calcite dissolution in $\mathrm{CO} 2$-water systems at $5^{\circ} \mathrm{C}$ to $60^{\circ} \mathrm{C}$ and 0.0 to $1.0 \mathrm{ATM} \mathrm{CO} 2 . \mathrm{Am}$ J. Sci. 278, 179-216. doi: 10.2475/ajs.278.2.179

Rabalais, N. N., Diaz, R. J., Levin, L. A., Turner, R. E., Gilbert, D., and Zhang, J. (2010). Dynamics and distribution of natural and human-caused hypoxia. Biogeo 7, 585-619. doi: 10.5194/bg-7-585-2010

Raich, J. W., and Tufekcioglu, A. (2000). Vegetation and soil respiration: correlations and controls. Biogeochemistry 48, 71-90. doi: 10.1023/A: 1006112000616

Raymond, P. A., Oh, N. H., Turner, R. E., and Broussard, W. (2008). Anthropogenically enhanced fluxes of water and carbon from the Mississippi River. Nature 451, 449-452. doi: 10.1038/nature06505

Richardson, M., and Kumar, P. (2017). Critical zone services as environmental assessment criteria in intensively managed landscapes. Earths Fut. 5, 617-632. doi: 10.1002/2016EF000517

Sampson, F., and Knopf, F. (1994). Prairie conservation in North America. BioScience 44, 418-421. doi: 10.2307/1312365 
Saxton, K. E., and Rawls, W. J. (2006). Soil water characteristic estimates by texture and organic matter for hydrologic solutions. Soil Sci. Soc. Am. J. 70, 1569-1578. doi: $10.2136 /$ sssaj2005.0117

Schilling, K. E. (2002). Chemical transport from paired agricultural and restored prairie watersheds. J. Environ. Q. 31, 1184-1193. doi: 10.2134/jeq2002.1184

Schilling, K. E., Manoj, K. J., Zhang, Y. K., Gassman, P. W., and Wolter, C. F. (2008). Impact of land use and land cover change on the water balance of a large agricultural watershed: historical effects and future directions. Water Resour. Res. 44:W00A09. doi: 10.1029/2007WR006644

Schilling, K. E., Streeter, M. T., Bettis, E. A. III, Wilson, C. G., and Papanicolaou, A. N. (2018). Groundwater monitoring at the watershed scale: an evaluation of recharge and nonpoint source pollutant loading in the clear creek watershed, Iowa. Hydrol. Process. 32, 562-575. doi: 10.1002/hyp.11440

Singh, G., Kaur, G., Williard, K., Schoonover, J., and Kang, J. (2018). Monitoring of water and solute transport in the vadose zone: a review. Vadose Zone J. 17:160058. doi: 10.2136/vzj2016.07.0058

Soil Survey Staff (1999). Soil Taxonomy: A Basic System of Soil Classification for Making and Interpreting Soil Surveys. Agriculture Handbook 436. Natural Resources Conservation Service, 2nd Edn. Washington, DC: USDA.

Soil Survey Staff (2018). Natural Resources Conservation Service, United States Department of Agriculture. Web Soil Survey. Available at: https://websoilsurvey. sc.egov.usda.gov/ [accessed 08/27/2018].

Tsypin, M., and Macpherson, G. L. (2012). The effect of precipitation events on inorganic carbon in soil and shallow groundwater, konza prairie lter site, NE Kansas, USA. Appl. Geochem. 27, 2356-2369. doi: 10.1016/j.apgeochem.2012. 07.008

Udawatta, R. P., Anderson, S. H., Gantzer, C. J., and Garrett, H. E. (2008). Influence of prairie restoration on CT-measured soil pore characteristics. J. Environ. Q. 37, 219-228. doi: 10.2134/jeq2007.0227
Vero, S. E., Macpherson, G. L., Sullivan, P. L., Brookfield, A. E., Nippert, J. B., Kirk, M. F., et al. (2018). Developing a conceptual framework of landscape and hydrology on tallgrass prairie: a critical zone approach. Vadose Zone J. 17:170069. doi: 10.2136/vzj2017.03.0069

Weihermuller, L., Siemens, J., Deurer, M., Knoblauch, S., Rupp, H., Gottlein, A., et al. (2007). In situ soil water extraction: a review. J. Environ. Qual. 36, 1735-1748. doi: 10.2134/jeq2007.0218

Wilson, C., Keefer, L., Abban, B., Wacha, K., Dermisis, D., Giannopoulos, C., et al. (2018). The intensively managed landscape critical zone observatory: a scientific testbed for agroecosystem functions and services. Vadose Zone J. 17:180088. doi: 10.2136/vzj2018.04.0088

Wright, C., and Wimberly, M. (2013). Recent land use change in the western corn belt threatens grassland and wetlands. Proc. Natl. Acad. Sci. U.S.A. 10, 4134-4139. doi: 10.1073/pnas.1215404110

Zhang, Y. K., and Schilling, K. E. (2006). Increasing streamflow and baseflow in Mississippi River since the 1940s: effect of land use change. J. Hydrol. 324, 412-422. doi: 10.1016/j.jhydrol.2005.09.033

Conflict of Interest Statement: The authors declare that the research was conducted in the absence of any commercial or financial relationships that could be construed as a potential conflict of interest.

Copyright (C) 2019 Dere, Miller, Hemje, Parcher, Capalli and Bettis. This is an openaccess article distributed under the terms of the Creative Commons Attribution License (CC BY). The use, distribution or reproduction in other forums is permitted, provided the original author(s) and the copyright owner(s) are credited and that the original publication in this journal is cited, in accordance with accepted academic practice. No use, distribution or reproduction is permitted which does not comply with these terms. 